\title{
Liberating Legal Education: \\ Using Critical Feminist Pedagogy to Educate on the Problems of Oppression and Gender-Based Violence
}

\author{
by
}

\section{Darby Babin}

A thesis submitted to the Faculty of Graduate and Postdoctoral Affairs in partial fulfillment of the requirements for the degree of

\author{
Master of Arts \\ in Legal Studies
}

Carleton University Ottawa, Ontario

Unceded Algonquin Territory

(C) 2018

Darby Babin 


\begin{abstract}
Both the criminal justice system and post-secondary institutions have deep histories of racism, inequality, and misogyny. Recent legislative changes have sought to remedy this reality through policy and judicial education. This thesis takes up these issues by arguing that post-secondary institutions, especially law schools, should dismantle these inequalities by ensuring that students are educated on these difficult issues prior to the beginning of their legal careers. This thesis uses both theoretical and empirical work to show that critical feminist pedagogies should be used in order to challenge the inequality present in academic institutions, and present students with a broader understanding of oppression and gender-based violence. It presents a practical application of progressive pedagogies and how relational theory can help bridge the gap between privilege and experience when dealing with subjects of oppression and violence.
\end{abstract}




\section{Acknowledgements}

I would like to start by thanking the one person who has made my life possible: my Dad, Rene Babin. Poppa Weasley, there will never be enough time, enough words, or enough space to thank you for what you have done for me. You are the strongest person I have ever met, your kindness seems to have no limits, and your resilience is absolutely remarkable. You have been there every step of the way. You have been two parents in one; my guidepost for everything. To give somebody a life is more than a "thank you" can cover, and I have endeavoured to live in a way that would make you proud. I hope that I have done a good job. I love you.

To my supervisor, Dale Spencer: thank you for your encouragement, kindness, and vulnerability. Thank you for ensuring that my project was fun and dynamic. Thank you for challenging me and always leaving space for laughter. You said that in the grand scheme of things your role in this project is ultimately "nothing", but for neither the first nor the last time in this journey, I have to say that I disagree with you. Thank you for everything. To my committee members, Diana Majury and Sophie Tamas: thank you for agreeing to join our team and for lending your insights and positive attitude to the final stretch of my project. Your impact has been invaluable. I would also like to thank Professor Gillian Calder at the University of Victoria for her generosity and kindness.

None of my work would be possible without a remarkable team of women who have encouraged and supported me more than any person deserves. To the fierce team in 
The Department of Equity Services: Carrolyn Johnston, Lauralee Archibald, Smita Bharadia, Jenna Easton, and Bailey Reid, I am so proud to know all of you.

Carrolyn, I cannot imagine what I would have done without your presence in my life. You are an incredible mom, feminist, and role model, and an even more remarkable friend. Thank you for letting me bounce ideas off of you; for letting me be my imperfect self around you; and for taking a chance on me when I started this program. You helped make Ottawa home again, and I love you for that and so much more. I know that this would not have been possible without your support. Lauralee, there is so much to thank you for. You have been there for me through this entire process, and you welcomed me so openly into your world when I showed up at the front desk. Thank you for encouraging me. Thank you for listening to me. Thank you for being there for me. You are a force of nature and I have an unwavering faith in you. You are braver, kinder, and more compassionate than any of us could ever hope to be. Thank you for being exactly who you are. Smita, every time I sit down and chat with you I learn so much more. You are equal parts fierce as you are loving and I am thankful for your laughter and dedication. Thank you for opening so many doors for me, and for always letting me talk longer than I should. Jenna, you will always be effortlessly cool in my mind. You do everything with such love, intention, and class. It has taught me so much about patience, sensitivity, and compassion. Thank you for letting me be flawed and often emotional. Thank you for being there and for always having the answers. I am so thankful that you are out there doing the work you do. Bailey, thank you for filling my last few months 
with so much laughter and aspiration haircuts. You are truly an icon. Your work ethic is outstanding and I cannot wait to see what you do next. It's been a privilege to work alongside all of you.

And to Alicia Poole in the Department of Safety, a friend and role model, I am so thankful for our work together. Thank you for being my teammate through this year, and for letting me make mistakes as I learned on my feet. Thank you for telling me stories about your life, and always being up for cup of coffee and a laugh. You have become such a source of inspiration for me and I am very proud to know and love you.

Beyond the walls of this university, I have spent my life in two different provinces. One which will always be in my heart and another which I now call home. I am overwhelmed with gratitude to the people who have been by my side in both British Columbia and Ontario. To the women who have been with me since our dreary teen years in Victoria, BC: Clarisa Greene, Samantha Wilson, Liv Jackson, Jes Cunningham, and Chantale Picard: I know in my heart how much your support has changed my life.

Clarisa, you are the root of the root. We have been together for almost half of our lives and I would not change a second of it. Thank you for being my heart and my family. I know it has not always been easy (we have seen some things!), but we have always been there to give one another momentum. I will always be proud of that. I love you, honeybear. Sam, we have spent a decade together, and I am so thankful for the past 10 years of shenanigans. You have an unparalleled strength. You have made me laugh harder than I ever thought possible, and you have loved me even when I did not deserve 
it. Thank you for always reminding me that it is okay to not be okay. Every part of me is proud of you. Liv, my girl, you have always reminded me that it is not only okay to relax, but that it is necessary. That sometimes you need to let go, laugh harder than you thought possible, maybe even dance it out a little bit. Thank you for being my first ever visitor in my new city 7 years ago, and thank you for always making time to see me when I am back by the sea. It has been such an honour to watch your life change and evolve. I have never doubted for a second what you could accomplish, and I know in my heart that you have never doubted me either. Thank you for that gift. Jes, my best good friend, I love you. Thank you for including me in your family. Thank you for letting me be Ollie's Auntie, and for never failing to be there for me when I have needed you. Your strength is unlike any other, your talents are limitless, and your generosity has been invaluable to my life. I am in constant awe of you. I will save the rest for my Maid of Freaking Honour speech.

Above all, to Chantale - my Life Wife, my soul sister-you got me here. Whether you will ever truly know that or not, you did. Thank you for filling out Carleton's address when we sent my transcripts all those years ago. Thank you for editing long, tiring chapters, and for your constant support of my project. Thank you for being a champion of long distance friendship; the compassion, care, and energy that we have put into our relationship remains such an integral part of who I am. I have said it before and I will say it a million times: you are my hero. I love you, between two lungs. 
There are three very special women who made Vancouver another place to call home, all of whom I am endlessly grateful for and indebted to: Kaitlyn Samson, Kendra Tubbs, and Kate Robinson. I love you all so very much. Kaitlyn, you have kept me grounded, laughing, and focused. You have always been there to enjoy the small things, decompress, and get through the longest shifts of our lives. Thank you for saying "yes" when I said “you're weird too!”. Ken, you have kept me strong, sane, and sassy. Thank you for your vulnerability, your open heart, and your fierce realness. Your ability to start over and build yourself the life that you deserve has inspired me in ways I can never explain. You are something to behold. Kate, I know that we would have been together no matter what because of our step-family-in-law-ties, but your friendship has been such a source of joy in my life. In every way, you are one in a million. There is no one else with your tenacity, humour, and fortitude.

To the friends who helped make Ottawa the home I wanted to come back to, you have been vital to my journey. First and foremost: Toni. You are the one person who has been my side since the first year of our undergrad at Carleton, and that has been one of the greatest parts of this experience. Our regular family dinners provided a source of comfort and stability when I needed it the most. Your ability to be so open, honest, and bold, became a model for me to strive towards. Your tenacity and courage are unparalleled; you are unlike any person I have ever met in my life. I am so proud of you and I love you very much. Rebekah, meeting you at the end of our undergrad changed my life for the better. Thank you for making me laugh and encouraging me to believe in 
myself. I am not sure I would have had the confidence to apply to grad school if not for your support. Thank you for always commiserating over the small things and the big things, for not letting distance change our friendship, and for always making time for munch. To Geneva, thank you for being my friend across many moves and moons. Finding you in fourth year was nothing short of kismet, and I am grateful that we were able to move our friendship from Ontario to British Columbia and back again. Thank you for all of the time we were able to spend together while I was in Vancouver; for holding me while I cry, for always having room for brunch, and for believing in doughnuts as an appetizer for tacos. I am constantly amazed by your boldness, your grit, and your open mind. My forever Queen. Finally, thank you to my dear friend Farheya Ahmed. You are wise beyond your years and carry with you a truly enchanting energy. Thank you for allowing me to hear your stories, for trusting me, and for always teaching me what empathy and vulnerability look like. I hope you always remember that you are valuable and important. You have the strength that you need. I promise.

To Sarah Brandon, Dillon Black, and Molly McAlea, thank you for reminding me why I moved back to this city by welcoming me into your lives. It has made this experience significantly brighter. Sarah, it has been a roller coaster, but I am thankful we were on that ride together. I am proud of you and how much you have endured. Never doubt your significance in this world. Dillon, you are absolutely extraordinary. Thank you for embracing me and my soft heart, for opening up to me and for encouraging me to keep doing the work. Your impact on this community cannot be understated. Thank you 
for letting me be a part of that in some small way. I love you and am honoured to call you my friend. Molly, my best witch, thank you for casting your positivity and honesty onto my life. Your support and encouragement through this thesis process has been such a source of stability for me. Thank you for embracing my friendship so fully and for sticking by me through such a wild ride so early in our time together.

Sometimes clichés are clichés for a reason—-like becoming best-friends with your grad school roommate, or meeting the love of your life in a graduate seminar. To the person who made our on-campus suite feel like home, Lisi Aman, I miss you desperately. You made me laugh every day, even when things were hard and we were too tired to even make a cup of coffee. Hollering at each other from our beds to get up and get to work remains one of the best memories of my life, and there is no shortage of those where you're concerned. Thank you for making schnitzel and watching The Sound of Music with me even though it drives you crazy. Thank you for always taking care of me, for being there when I needed you, and for making the distance between Austria and Ottawa feel like nothing at all. Most of all, thank you for including me into your life. I will never stop hoping that you'll be there when I get home. I promise I will see you soon. I love you.

And to my partner, Drew Hoult, knowing you has made the biggest difference of all. Thank you for being exactly who you are. Thank you for believing in me, for editing my work, and for lending me so much of your bookshelf. I am constantly in awe of our teamwork and collaboration; our endless discussions about feminism, privilege, and 
capitalist structures have been both the most fun I have ever had and important reflections for my work. You have supported and encouraged me in ways I never knew that I deserved; loving you and being loved by you has challenged me and changed me irrevocably. Thank you for never giving up. I love you and I like you. I am overwhelming proud of you.

To my MA Legal Studies women: Deepa Nagari, Lauren Menzie, Taryn Hepburn, and Nicole Uloth, thank you for being my teammates. I cherish you and our memories together. Our time spent locked up in MacOdrum, although often stressful and filled with exclamations of exhaustion, was incredible and invaluable. Our trips to almost every coffee shop in Ottawa boosted my spirits (and likely the local economy). We did it!

Family is a choice, and all of these remarkable human beings are part of the family that I have chosen and has chosen me. I am so lucky that my siblings have chosen me, too. My little brother, Arin Wright, and my older sister, Caitlin Iddins-Babin, are the best parts of who I am. Our life has not always been simple and easy, and there have been moments where the choice to be a family was more difficult than others; but still, we made it.

Arin, you have been everybody's favourite from the moment you entered the world (I think at this point it may have gone to your head). You have a remarkably sharp wit and a presence which is both comforting and exciting. You make all of us laugh harder than we could ever imagine. Your life has not been easy and yet you have not let it harden you or make you bitter. I am so proud of who you have grown up to be, and I am 
in awe of your strength. You teach me so much. To be your sister is a privilege. Caitlin, my Little Big, I love you. Your heart is home to the most remarkable empathy. Your mind has always been inquisitive, open, and filled with brilliance. You have a quiet strength that has been there our whole lives - seeing and feeling everything we experienced, trying to make sense of it. I know that you have kept me safe in ways I will never fully remember. Thank you. Until the very end.

To my stepmom, Leslie, thank you for your support, encouragement, and culinary skills. Thank you for picking up the phone and providing me with so many things that I needed. Your presence in my life has helped me in innumerable ways. I will always be thankful for that. To my grandparents, Edward and Marion Iddins, you have supported Arin, Caitlin, and me in so many important ways. Thank you for giving us a place to come together and still feel like a family. I love you unconditionally. To my uncle Keith, however far away you are geographically, you've been in our hearts all along. You were, and are, a reflection of what we could be - that we can be silly, brave, and unabashedly ourselves.

To all of the women in my life - my home team, my West Coast babes, my Ottawa loves, my sisters - you have enriched my life every day and I would not be me without you. You are my insides. I love you. There are so many more people I could thank, but I am sure the music will start playing me out and I should wrap this up. I am privileged in many ways, not the least of which is to have an inexhaustive list of people 
to thank for their love. I will never feel deserving of such unconditional support. Life with all of you is a dream.

Finally, to all of the survivors of gender-based violence - those who are in situations in which it is safe to come forward and those who are not-I see you and I believe you. Please know that you are loved, your feelings are valid, and you deserve to be heard. To all the feminist activists and advocates, I know that you are tired. I am tired, too. Remember to take breaks, to lean on your sisters, and to cry when you must. I promise that one day we will win this war. This is for you. 


\section{Table of Contents}

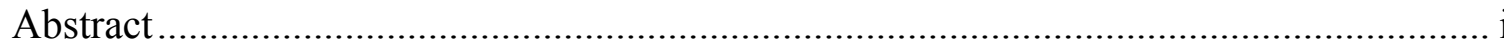

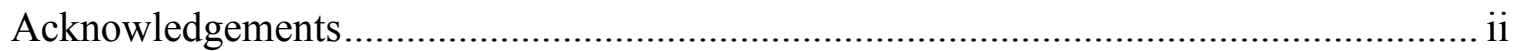

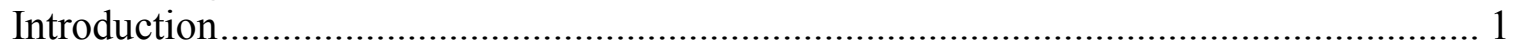

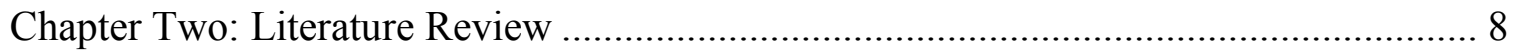

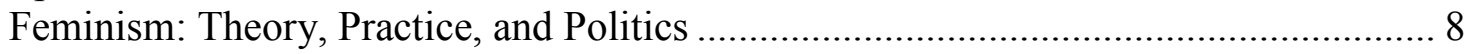

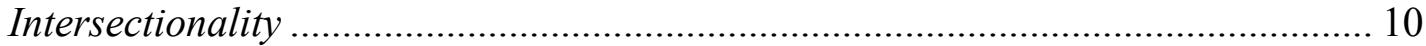

Gender-Based Violence and Sexual Violence .................................................... 12

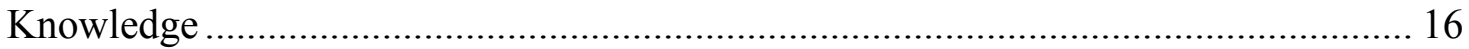

Standpoint Theory and Feminist Epistemology ……….................................... 18

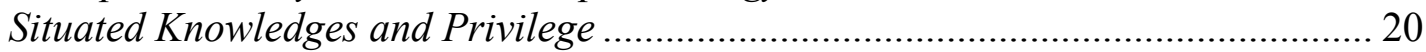

Pedagogy \& Practice .............................................................................................. 24

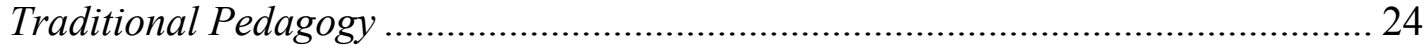

Pedagogy of the Oppressed: Liberatory Pedagogy …………............................... 26

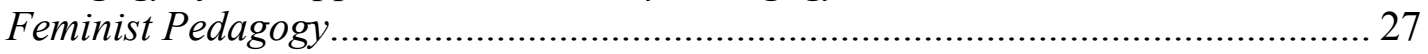

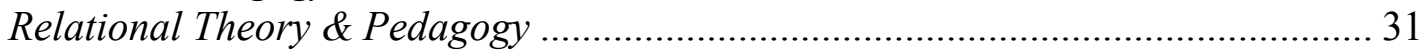

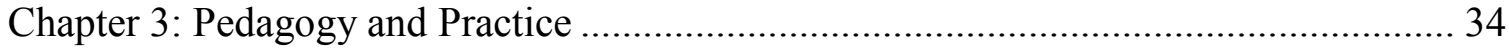

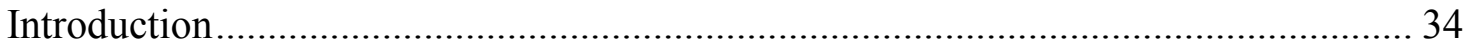

Inequality in Canadian Law Schools: Gender, Race, and Indigeneity ......................... 35

Paulo Freire: Building Liberatory Pedagogy ........................................................... 38

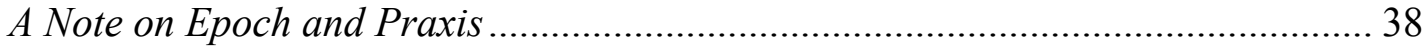

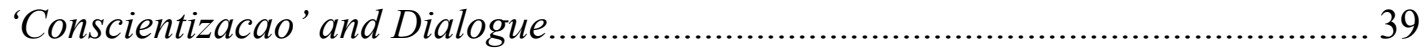

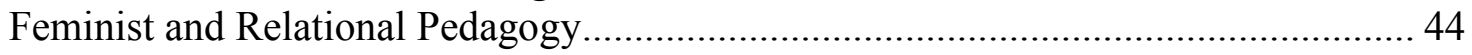

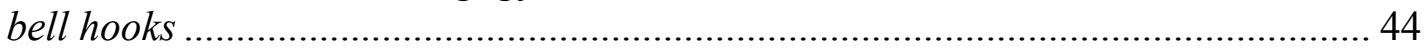

Relationality \& The Limitations of Experiential Education and Community Service

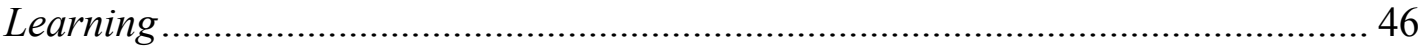

Conflicts, Feelings, and Conflicting Feelings ........................................................... 50

Embodied Emotions and Affective Responses...................................................... 50

Paradoxes of Privilege and Situated Knowledges .................................................. 53

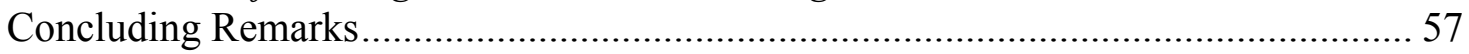

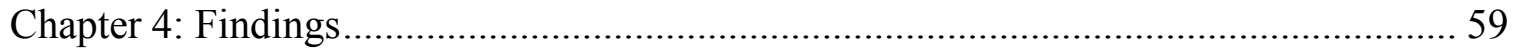

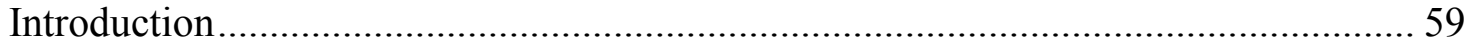

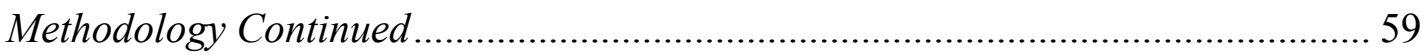

The Landscape of Canadian Law Schools: Course Offerings in JD Programs ............ 64

Case Study: Theatre and Embodied Pedagogy at The University of Victoria.............. 67

Reflections from Professor Gillian Calder, Associate Dean of Law ......................... 67

Family Law and the Theatre of the Oppressed ....................................................... 73

Queries and Concerns: Role-Play, Embodied Trauma, and Relationality............... 75

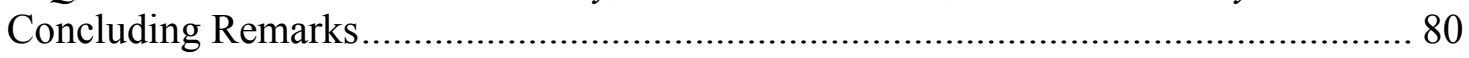

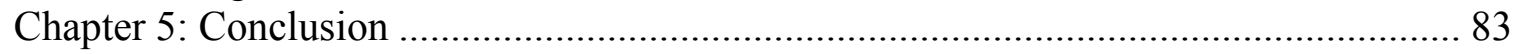

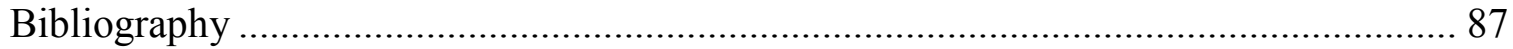


Table of Tables

Table 1: Feminist and Gender-Based Violence Course Offerings in JD Programs . 65

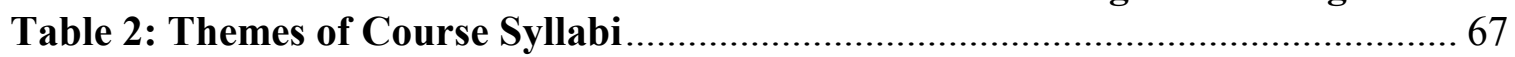




\section{Introduction}

In February of 2017, Rona Ambrose introduced a Private Member's Bill which would mandate federal judges to undergo training on the issue of sexual assault. Additionally, this Bill sought to amend the Criminal Code to require written reasoning for the decisions in sexual assault cases. ${ }^{1}$ The introduction of this Bill followed public outcry against judicial behaviour in numerous sexual assault trials. To say that there is a gender-bias in the law is not new or revolutionary and the relationship between sexual assault and the legal system is volatile at best. ${ }^{2}$ Victims and survivors of gender-based violence have historically been ignored and mistreated by the criminal justice system. This issue has come to a head as of late. Attention has been drawn to the rates of unfounded cases in each Canadian district, campuses have been legislated to have standalone sexual violence policies, and popular feminist movements have continued to raise awareness to the epidemic of sexual assault in every industry.

When Bill C-337 was introduced, Rona Ambrose was the interim leader of the Conservative Party of Canada and I was beginning my work as a facilitator of sexual assault resistance education through the Department of Equity Services at Carleton

\footnotetext{
${ }^{1}$ Bill C-337, An Act to amend the Judges Act and the Criminal Code (sexual assault) $1^{\text {st }}$ Sess., $42^{\text {nd }}$ Parl., Canada, 2017 (first reading 23 February 2017).

${ }^{2}$ Elizabeth Sheehy ed, Sexual Assault in Canada: Women, Law, and Legal Activism (Canada: University of Ottawa Press, 2012); Defending Battered Women on Trial: Lessons from the Transcripts (Canada: UBC Press, 2014); Laura L. O’Toole \& Jessica R. Schiffman eds., Gender Violence: Interdisciplinary Perspectives (New York: New York University Press, 1997); Walter S. DeKeseredy, Violence Against Women: Myths, Facts, Controversies (Canada: university of Toronto Press, 2011); Isabel Grant, "Intimate Partner Criminal Harassment Through a Lens of Responsibilization” (2015) Osgoode Legal Studies Research Paper Series 87.
} 
University. This is what drew my attention to her call for legal education. Given the instances of Canadian judges speaking inappropriately toward survivors of sexual assault, the idea behind Ambrose's Bill is admirable; calls for legal reform have been a popular method of feminist mobilization despite the limited success of such victories. It is important to have judges who are trained in the area of sexual assault and gender-based violence more broadly, but I question why the Canadian government would wait until legal practitioners are already judges before they are required to complete such training. Legal professionals should have — at minimum — a basic understanding of the context and history of gender-based violence in Canada. They should not be sitting on the bench, already hearing the story of a survivor, before they understand the complex experiences of survivors. Lawyers and judges are not created out of thin air. There are several layers of education and training that are required before a person can practice the law.

As a response to Bill C-337, the focus of this project is legal education. Not only do I believe it would be beneficial to train judges on the subject of sexual assault law, but it would also be extremely beneficial to ensure that no lawyer makes it to the position of judge without having experienced any training on the subject of gender-based violence. Therefore, there should be greater focus on this problem in all post-secondary institutions. For example, my undergraduate degree was part of a BA Honours program in Law. My concentration was the Transnational Law and Human Rights stream, but my course options around gender and the law were limited. Most courses that involved an analysis of gender were outside of the Department of Law and Legal Studies. In the final 
year of my Bachelor's degree, I took a course on international law and armed conflict. When going over the syllabus, the professor admitted to having removed the week on feminist perspectives due to time and space. I voiced my concerns and was told that I could use feminist perspectives in my final paper, and that the professor would send me the readings that he originally intended for the class. I am lucky to have and maintain a good working relationship with this professor and was in the position to safely voice my concerns. As I will discuss later in this thesis, that is not the case for all students. Over the first year of my Master's degree, I found it difficult to choose classes that were related to my research interest in gender-based violence and feminist legal theory. For the most part the courses simply were not offered, and when they were available, they were outside of the Department of Law and Legal Studies. As a result, I have often had to force my research interests into the content of the courses available to me.

This thesis will open with a concept-based literature review in its first substantive chapter. The main themes include feminism, intersectionality, gender-based violence, pedagogy, and theories of knowledge. From there, I will move into a more in-depth discussion of both pedagogy and practice. This will include a discussion on contemporary Canadian law schools as well as the main theories of pedagogy and feminist practice that serves as the foundation for this work. This chapter will centre around the theories of Paulo Freire and bell hooks, both of which argue for liberatory pedagogies. Moreover, indigenous, feminist, and relational theories will be introduced and discussed as integral to building an interdisciplinary relational pedagogy. Following this, the chapter on 
findings will provide the data that I collected as part the qualitative analysis of this thesis. This will include a case-study using material electronically accessed from the University of Victoria. Finally, this thesis will conclude with a chapter that discusses what education on gender-based violence could look like in the future. I will return to the theories discussed in Chapter 2 to argue for a dynamic, interdisciplinary pedagogy moving forward.

Throughout this thesis I will argue that a critical feminist relational pedagogy needs to be further developed. Such a pedagogy should not only be used to teach on the subject of gender-based violence and oppression, but all subject-matter. The absence of this pedagogy ensures the persistence and reaffirmation of various forms of marginalization. Marginalization is not only present in certain aspects of law and society, but in all facets of life. Marginalization is not something that can be removed from the lived reality of those who experience discrimination, inequality, and often violence. Relational theory provides the theoretical lens to engage with issues of marginalization in meaningful ways across all disciplines. This project is theoretical, empirical, and practical in its application in order to present a dynamic and constructive contribution to the conversation of liberatory pedagogy. I present a critical but encouraging case for how law school — and post-secondary institutions as a whole — can incorporate critical feminist pedagogy into their curriculum. 


\section{Methodology}

In part, this thesis will use personal narrative. This method is not uncommon among feminist research. ${ }^{3}$ With the acknowledgement that research is not carried out by "a shadowy figure", the use of first person has become increasingly popular in the social sciences. ${ }^{4}$ This demonstrates to the reader that the researcher has been reflexive and understands the ways in which their positionality affects their research. The dangers with the inclusion of emotions and the personal in academic work is the privileging of the author's experience over that of the research data. ${ }^{5}$ Additionally, Laura Kauffman cautions that when using personal narrative there is a tendency to use that voice to create hierarchies of suffering or that "we", as feminists, end up speaking only to ourselves. She concludes, however, that "our" (feminist) work is "directly related to our personal histories; that our subjective experiences influence our politics, that our psychic traumas affect our teaching and writing". ${ }^{6}$

I chose to use personal narrative in this thesis because of my position as a feminist law student, and the Facilitator/Coordinator of The Enhanced Assess, Acknowledge, Act

\footnotetext{
${ }^{3}$ Sarah Ahmed, Living a Feminist Life (Durham, NC: Duke University Press, 2017); Susan Archer Mann, Doing Feminist Theory: From Modernity to Postmodernity (New York: Oxford University Press, 2012); bell hooks, Feminist Theory: From Margin to Center (Cambridge, MA: South End Press, 1984); Ain't I A Woman: Black Women and Feminism (Boston, MA: South End Press, 1991); Teaching to Transgress: Education as the Practice of Freedom (New York: Routledge, 1994); Teaching Community: A Pedagogy of Hope (New York: Routledge, 2003); Patti Lather, Getting Smart: Feminist Research and Pedagogy With/In the Postmodern (New York: Routledge, 1991); Meg Luxton \& Mary Jane Mossman, Reconsidering Knowledge: Feminism and the Academy (Canada: Fernwood Publishing, 2012).

${ }^{4}$ Rebekah Widdowfield, "The Place of Emotions in Academic Research" (2000) Area 199.

${ }^{5}$ Supra.

${ }^{6}$ Laura Kauffman, "The Long Goodbye: Against Personal Testimony or An Infant Grift Grows Up" in Laura Kauffman ed, American Feminist Thought at Century's End: A Reader (Oxford: Blackwell, 1993) at 259.
} 
Program (EAAA) - a 12-hour sexual assault resistance education program at Carleton. Additionally, I volunteer as a peer supporter at Carleton's Sexual Assault Support Centre. In this role, I handle disclosures of violence and abuse and help survivors with resources both on and off campus. Lastly, I sit as the graduate student on Carleton's Sexual Violence Education and Prevention Committee.

Due to my discussion of feminist epistemology and pedagogy, it would be disingenuous to remove myself entirely from this piece of work. It is common in social sciences to reduce personal narrative "to the status of anecdotal, adding color or personal interest but unreliable as a basis for generalization". ${ }^{7}$ While personal narrative has been used to elevate voices of those traditionally left out of historical narratives, it is also used to connect the individual to the social. ${ }^{8}$ This is connected to the theories of standpoint feminist epistemology and relationality that will be discussed later in this thesis. As Maynes, Pierce, and Laslett argue, each personal narrative is unique but "can only be understood in light of their social, cultural, and historical context". ${ }^{9}$ The difficulty of personal narrative is that it does not necessarily reach concrete conclusions. The evidence produced by personal narrative is often contingent and serves to "exemplify an argument that is nevertheless made according to another logic". ${ }^{10}$ This thesis uses personal

\footnotetext{
${ }^{7}$ Mary Jo Maynes, Jennifer L. Pierece, and Barbara Laslett eds, Telling Stories: The Use of Personal Narratives in the Social Sciences and History (New York, NY: Cornell University Press, 2008).

${ }^{8}$ Supra.

${ }^{9}$ Ibid at 127.

${ }^{10}$ Ibid.
} 
narrative in combination with theory to highlight the implications generated by the data, as well as through the collection of the data itself. 


\section{Chapter Two: Literature Review}

\section{Feminism: Theory, Practice, and Politics}

In 1949, Simone de Beauvoir grappled with whether or not she should continue to write about women. She said, "[e]nough ink has been spilled in quarrelling over feminism, now practically over, and perhaps we should say no more about it". ${ }^{11}$ Decades later we are still spilling ink over the subject of feminism. The definition of feminism is often personal, although the varying definitions of feminism revolve around a similar interest in challenging normative structures of gender, race, and class. ${ }^{12}$ Feminism has advocated for abortion rights, suffrage, pay equity, and bringing an end to violence against women. ${ }^{13}$ Traditionally these struggles have focused on "women" as cis-gender, straight, white women. ${ }^{14}$ Notorious for troubling the idea of gender, Judith Butler defines feminism as "the social transformation of gender relations". ${ }^{15}$ Butler views gender as a performance that is continually reproduced, and it is through this performance that subjectivity is produced. ${ }^{16}$ Her work describes the treatment of queer folks not only as

\footnotetext{
${ }^{11}$ Simone de Beauvoir, The Second Sex (New York, NY: Vintage Books, 1989).

12 Robin Moran ed, Sisterhood is Forever: The Women's Anthology for a New Millennium (New York: Washington Square Press, 2003), [Moran]; Adrien Katherine Wing ed, Critical Race Feminism (New York: New York University Press, 1997), [Wing].

${ }^{13}$ Moran, Wing, supra.

${ }^{14}$ Wing, ibid; Kimberlé Crenshaw, Neil Gotanda, Gary Peller, \& Kendall Thomas eds, Critical Race Theory: The Key Writings that Formed the Movement (New York: The New Press, 1995); bell hooks, Sisters of the Yam: Black Women \& Self-Recovery (Toronto, ON: Between The Lines, 1993); Himani Bannerji ed, Returning the Gaze: Essays on Race, Feminism, and Politics (Toronto, ON: Sister Vision Press, 1993).

15 Judith Butler, Undoing Gender (New York: Routledge, 2004), [Butler, 2004]; Gender Trouble (New York: Routledge Classics, 2006), [Butler, 2006]; Bodies That Matter: On the Discursive Limits of Sex (New York: Routledge, 1993), [Butler, 1993].

${ }^{16}$ Butler, 2006, supra.
} 
oppression, but as abjection. This abjection continues when the subjectivity of gender is dismissed as a copy of heteronormativity. ${ }^{17}$

The work of bell hooks has significantly shaped my understanding of feminism and race, as well as my continued interest in intersectionality. hooks describes feminism as "a movement to end sexism, sexist exploitation, and oppression". ${ }^{18}$ When hooks began writing, black women were excluded from the experience of "women", and intersectional analysis had yet to be made popular. ${ }^{19}$ hooks's identity and self is fundamentally present in her work as a way to subvert the erasure of the experience of those who are oppressed. The crux of the definition provided by hooks is the use of 'sexism'. The acknowledgement of sexism identifies behaviour of both men and women. ${ }^{20}$ The feminist reliance on advocating for women has often left trans, non-binary, and genderqueer folks out of the discussion. ${ }^{21}$ Feminism is both a theory and a practice. It is "a mode of analysis [and] a method of approaching life and politics". ${ }^{22}$ This must include an analysis of the gender-binary and the ways that the feminist movement has upheld this binary at the

\footnotetext{
${ }^{17}$ Butler, 1993, supra.

18 bell hooks, Feminist Theory: From Margin to Center (Cambridge, MA: South End Press, 1984), [hooks, 1984]; Feminism is For Everybody: Passionate Politics (Brooklyn, NY: South End Press, 2006), [hooks, 2006]; Ain't I A Woman: Black Women and Feminism (Boston, MA: South End Press, 1991), [hooks, 1991]; The Will to Change: Men, Masculinity, and Love (New York: Washington Square Press, 2004), [hooks, 2004].

${ }^{19}$ Supra.

${ }^{20}$ hooks, 2006, supra.

${ }^{21}$ Butler, supra note 5.

${ }^{22}$ Sneja Gunew ed, Feminist Knowledge: Critique and Construct (New York: Routledge, 1990); A Reader in Feminist Knowledge (New York: Routledge, 1991).
} 
expense of trans, non-binary, and genderqueer folks; as well as the exclusion of indigenous and racialized women. ${ }^{23}$

As explained by Sara Ahmed, feminism is homework. ${ }^{24}$ It is work that must be done not just through the act of theory, but in our home and our daily experiences: "We have to bring feminist theory home because feminist theory has been too quickly understood as something that we do when we are away from home (as if feminist theory is what you learn when you go to school). When we are away, we can and do learn new words, new concepts, new angles". ${ }^{25}$ This understanding of feminism informs the way that this thesis engages with relational pedagogy and the way that our social positions affect our experiences.

\section{Intersectionality}

Kimberlé Williams Crenshaw introduced intersectionality as an analytical tool in her seminal piece, "Demarginalizing the Intersection of Race and Sex: A Black Feminist Critique of Antidiscrimination Doctrine, Feminist Theory and Antiracist Politics". Crenshaw critiques the discussion of race and gender as "mutually exclusive categories of experience and analysis". ${ }^{26}$ This work has been used to strengthen the analysis of

\footnotetext{
${ }^{23}$ Moran, supra note 2; Diane Richardson, Janice McLaughlin, \& Mark E. Casey eds, Intersections Between Feminist and Queer Theory (United Kingdom: Palgrave Macmillan, 2006); Dean Spade, Normal Life: Administrative Violence, Critical Trans Politics, and the Limits of the Law (Brooklyn, NY: South End Press, 2011).

${ }^{24}$ Sara Ahmed, Living a Feminist Life (Durham, NC: Duke University Press, 2017).

${ }^{25}$ Ahmed, supra.

${ }^{26}$ Kimberlé Crenshaw, "Demarginalizing the Intersection of Race and Sex: A Black Feminist Critique of Antidiscrimination Doctrine, Feminist Theory and Antiracist Politics" (1989) University of Chicago Legal Forum 139, [Crenshaw, 1989].
} 
marginalization by recognizing the effects of intersecting experiences of oppression. The context in which Crenshaw developed intersectionality was legal engagement with discrimination. The test for sex discrimination was rooted in the experience of the white woman, and this "single-axis" overlooked the experiences of oppression that face those with overlapping identities. That is, those who face intersecting forms of oppression, violence, and marginalization. ${ }^{27}$

Devon W. Carbado, Vickie M. Mays, Barbara Tomlinson, and Kimberlé Crenshaw explain that the movement of intersectionality into the international sphere "draws attention to how contextual differences generate alternative engagements with the theory". ${ }^{28}$ It has become a method of analysis, not only within legal studies, but within social sciences and humanities more broadly. The mobilization of intersectionality has helped to expand its usage to theory as well as practice. Sunny Marriner adopts intersectionality into her concept of feminist political practice. Feminist work "must be, by definition, anti-oppression work and actively challenge racism, classism, ableism, heterosexism, colonialism, and other forms of oppression" ${ }^{29}$ This account of feminist practice with an intersectional lens informs the analysis of legal education in this thesis, and the need for a liberatory pedagogy. This framework of analysis is pivotal to my

\footnotetext{
${ }^{27}$ Sumi Cho, Kimberlé Williams Crenshaw, \& Leslie McCall, "Toward a Field of Intersectionality Studies: Theory, Applications, and Praxis" (2013) Signs 875 [Cho, Crenshaw, \& McCall, 2013].

${ }^{28}$ Devon W. Carbado, Kimberlé Williams Crenshaw, Vickie M. Mays, \& Barbara Tomlinson, "Intersectionality: Mapping the Movements of a Theory" (2013) Du Bois Review 10(2), 303 [Carbado, 2013].

${ }^{29}$ Sunny Marriner, "Questioning Expert Knowledges" in Elizabeth Sheehy ed, Sexual Assault in Canada: Law, Legal Practice, and Women's Activism (Canada: University of Ottawa Press, 2012) 409 at 412.
} 
project as oppression is reinforced through all social and political institutions, including universities.

The intersectional lens provided by Crenshaw allows for an analysis of how traditional university structures affect those who are marginalized. For many indigenous and racialized students and professors, such institutions remain hostile and isolating. ${ }^{30} \mathrm{As}$ explained by Nolan Cabrera, university campuses exhibit "racial hyper-privilege" in which white men "hold a disproportionate amount of societal power relative to women and people of colour". ${ }^{31}$ This notion has been expanded upon by Frances Henry, Enakshi Dua, Carl E. James, Audrey Kobayashi, Peter Li, Howard Ramos, and Malinda S. Smith in The Equity Myth. They dispel the myth that Canadian universities are democratic and equitable spaces. ${ }^{32}$ In particular, they are critical of the reflexivity of social sciences as giving race and indigeneity the "epistemological status of silence". ${ }^{33}$ To create more equitable spaces, university classrooms must be conscious of race, indigeneity, and the use of intersectional analysis. ${ }^{34}$ Gender-Based Violence and Sexual Violence

\footnotetext{
${ }^{30}$ Sheila Cote-Meek, Colonized Classrooms: Racism, Trauma and Resistance in Post-Secondary Education (Canada: Fernwood Publishing, 2014).

${ }^{31}$ Nolan Cabrera, "Exposing Whiteness in Higher Education: White Male College Students Minimizing Racism, Claiming Victimization, and Recreating White Supremacy” (2014) 17 Race, Ethnicity, and Education 30 at 31 .

${ }^{32}$ Frances Henry, Enakshi Dua, Carl E. James, Audrey Kobayashi, Peter Li, Howard Ramos, \& Malinda S. Smith, "The Equity Myth: Racialization and Indigeneity at Canadian Universities" (Canada: UBC Press, 2017), [Henry et. al., 2017]

33 Supra at 243.

${ }^{34}$ Henry et. al., supra note 24; Faisal Bhabha, "Toward a Pedagogy of Diversity in Legal Education" 52 Osgoode Hall Law Journal 59.
} 
Gender-based violence includes a vast spectrum of behaviours, and it is not unusual for victims of gender-based violence to have experienced more than one type. ${ }^{35}$ This includes sexual violence, criminal harassment or stalking, and intimate partner violence (domestic violence). Sexual violence also covers a continuum of behaviours. This includes sexual assault, sexual harassment, voyeurism, groping, and more. In Canada, the Criminal Code does not use the word "rape", but sexual assault. ${ }^{36}$

These forms of violence are the result of gender inequality in society. ${ }^{37}$ This inequality is rooted in outdated ideas about gender such as those advanced by patriarchy, understood as the system of male dominance. ${ }^{38}$ The act of sexual violence is not about sex, but it is enacted through sex. This is significant because it serves as a method of male domination over women. ${ }^{39}$ Men are influenced by the dominant ideology surrounding them, which is often rooted in patriarchy and misogyny. ${ }^{40}$ For centuries that ideology has placed women in the role of subordinate. As explained by Emilie Buchwald: "Boys take in misogyny with their Wheaties. They are shown by mentors and peers that it won't do to spend much time with girls and women. No

\footnotetext{
${ }^{35}$ Isabel Grant, "Intimate Partner Criminal Harassment Through a Lens of Responsibilization” (2015) Osgoode Legal Studies Research Paper Series. 87 [Grant].

${ }^{36}$ Criminal Code, R.S.C., 1985, c C-46, s. 271; Elizabeth Sheehy ed, Sexual Assault in Canada: Women, Law, and Legal Activism (Canada: University of Ottawa Press, 2012), [Sheehy, 2012].

${ }^{37}$ hooks, 2004, supra note 8; Laura L. O’Toole \& Jessica R. Schiffman eds, Gender Violence: Interdisciplinary Perspectives (New York: New York University Press, 1997); It's Never Okay: An Action Plan to Stop Sexual Violence and Harassment (Minister Responsible for Women's Issues, March 2015) ${ }^{38}$ Supra.

${ }^{39}$ Catharine MacKinnon, "Sexuality, Pornography, and Method: Pleasure Under Patriarchy" (1989) Ethics 314.

${ }^{40}$ A. Gondezi, M.D. Schwartz, and W.S. Dekeseredy, "Toward A Gendered Social Bond/Male Peer Support Theory of University Woman Abuse" (2001) 10 Critical Criminology 1 at 4.
} 
boy wants to 'throw like a girl', or be told to go home to mama. When your teachers and your buddies tell you that girls are not only physically weaker but lack at the important virtues, including courage, strength, and rationality, why would you respect girls? It's easy to move from the idea that women are inferior to treating them as inferiors". ${ }^{41}$

Walter DeKeseredy has expanded on these ideas of gender and sexual violence. He states:

“discussions of prevalence that rely on the variables 'male' and 'female' cannot tell us much about gender, the socially constructed and normative set of meanings attached to these categories. This distinction is one of the primary contributions of feminist perspectives to the social sciences. Research that asks perpetrators and survivors about the nature of violence between intimates finds that both say much about gender. For example, violent men talk about threats to their masculinity when women or men fail to demonstrate adequate respect for them, whereas women talk about the normative gender expectations that abusers use to justify their violence". 42

Gender expectations have lasting impacts. This includes expectations around sexual activity. The traditional sexual script says that men are meant to pursue sexual activity

\footnotetext{
${ }^{41}$ Emilie Buchwald, "Raising Girls For the $21^{\text {st }}$ Century" in Emilie Buchwald, Pamela R. Fletcher, and Martha Roth eds, Transforming a Rape Culture (Minneapolis, MN: Milkwood Editions, 1993) at 183.

${ }^{42}$ Walter DeKeseredy, Violence Against Women: Myths, Facts, Controversies (Canada: University of Toronto Press, 2011) at 50.
} 
while women are meant to remain coy and say no. ${ }^{43}$ Jozkowski, Peterson, Sanders, Dennis, and Reece explain that such scripts are part of a hegemonic masculinity that is particularly hetero-normative. ${ }^{44}$ The law is also rooted in these concepts which fails to address the roots of masculine violence. ${ }^{45}$

Survivors of gender-based violence are often reluctant to report because engagement with the criminal justice system tends to result in disappointment and additional harm. This is referred to as secondary victimization. ${ }^{46}$ Crimes of sexual violence are individualized within the frame of criminal law, which fails to account for the ways that myths and stereotypes about gender and violence contribute to its prevalence. ${ }^{47}$ Lise Gotell explains that through judicial reasoning, this individualization has discursively removed sexual violence from the context of gender-inequality. ${ }^{48}$ She

\footnotetext{
${ }^{43}$ Buchwald, supra; Corey Rayburn, "To Catch a Sex Thief: The Burden of Performance in Rape and Sexual Assault Trials" Colum. J. Gender \& L. 437; Susan Ehrlich "Perpetuating — and Resisting—Rape Myths in Trial Discourse" in Elizabeth Sheehy eds, Sexual Assault in Canada: Law, Legal Practice, and Women's Activism (Canada: University of Ottawa Press, 2012) 389.

${ }^{44}$ K.N. Jozkowski, Z.D. Peterson, S.A. Sanders, B. Dennis, \& M. Reece, "Gender Differences in Heterosexual College Students' Conceptualizations and Indicators of Consent: Implications for Contemporary Sexual Assault Prevention Education" (2014) 51 The Journal of Sex Research 904 at 905. ${ }^{45}$ John Braithwaite \& J. Daly, "Masculinities, Violence, and Community Control" in T. Newburn \& E. A. Stanko eds, Just Boys Doing Business? Men, Masculinities, and Crime (New York: Routledge, 1998) at 191.

${ }^{46}$ Grant, supra; Lise Gotell, "The Idea Victim, the Hysterical Complainant, and the Disclosure of Confidential Records: The Implications of the Charter for Sexual Assault Law" (2002) 40 Osgoode Hall Law Journal 251 [Gotell, 2002]; Jordan Fairbairn \& Dale Spencer, "Virtualized Violence and Anonymous Juries: Unpacking Steubenville's 'Big Red' Sexual Assault Case and the Role of Social Media” (2017) Feminist Criminology 1 [Fairbairn \& Spencer]; Lesley Laing, "Secondary Victimization: Domestic Violence Survivors Navigating the Family Law System" (2017) 23 Violence Against Women 1314; Debra Patterson, "The Linkage Between Secondary Victimization by Law Enforcement and Rape Case Outcomes" (2011) 26 Journal of Interpersonal Violence.

${ }^{47}$ Gotell, ibid; Grant, supra note 14.

${ }^{48}$ Gotell, 2002, supra.
} 
connects this to the ways in which private records are disclosed, arguing that rights claims (like that of a fair trial) "obscure the complexities of sexualized violence". 49

It is not uncommon for feminist organizations to serve as interveners in such cases to provide a community voice and contribute to the contextual understanding of sexual violence as rooted in gender inequality. ${ }^{50}$ It is not the position of this thesis that criminal law is the best or only avenue to remedy the problem of gender-based violence. Although acts of gender-based violence are governed by criminal law, it is a problem that permeates every facet of society and should remedied by law, public policy, and extensive social change. ${ }^{51}$

$\underline{\text { Knowledge }}$

History and Subjugated Knowledges

Michel Foucault describes knowledge as the quest for truth. In The Archaeology of Knowledge, he defines historical knowledge as that which relies on memory of the past. Historical knowledge lives through 'the document', which tells its reader what has come before them. In this way, historical knowledge is continuous. However, Foucault disrupts this idea of continuity by suggesting that history has ignored 'the Other' ${ }^{52}$ History has focused on long-periods of time without attention to the capillary stories.

\footnotetext{
49 Ibid.

${ }^{50}$ Sheehy 2012, supra note 27; Christopher P. Manfredi, Feminist Activism in the Supreme Court: Legal Mobilization and the Women's Legal Education and Action Fund (Canada: UBC Press, 2004).

${ }^{51}$ Lise Gotell, “The Discursive Disappearance of Sexualized Violence: Feminist Law Reform, Judicial Resistance, and Neo-Liberal Sexual Citizenship" in Dorothy E. Chunn, Susan Boyd, \& Hester Lessard eds, Reaction and Resistance: Feminism, Law, and Social Change (Canada: UBC Press, 2008), [Gotell, 2008$].$ ${ }^{52}$ Michel Foucault, The Archaeology of Knowledge and the Discourse on Language (New York: Vintage, 2006), [Foucault 2006].
} 
Politics, science, and society can come to be known through the analysis of large sections of time and memory, but that analysis does not account for the facets of life that are interrupted and changed. The account of history that brings knowledge is traditionally that of men. Foucault brings to light that there were, and are, other sources of knowledge. ${ }^{53}$

These other sources of knowledges are explained as "subjugated knowledges": knowledges that have been ignored by dominant discourses. Moreover, entire ways of knowing have been treated as less than by dominating powers. ${ }^{54}$ Knowledge, like power, is not monolithic. It is built and passed on through structures of discursive power that permeate institutions of law, religion, medicine, politics, and education. ${ }^{55}$ Through the reproduction of power and knowledge, subjects are created and controlled. Judith Butler uses this to trouble heteronormative understandings of gender which are reproduced through discourse and performance. ${ }^{56}$

This idea of discursive power is also reflected in feminist epistemology. Individual experiences are seen as a source of knowledge that is constituted through discourse.$^{57}$ The raising of voices that are traditionally marginalized or subjugated can be seen as an example of Butler's discursive power and performance. The use of feminist

\footnotetext{
${ }^{53}$ Supra.

${ }^{54}$ Michel Foucault, The History of Sexuality Volume I: An Introduction (New York: Random House, 1978), [Foucault, 1978].

${ }^{55}$ Foucault 1978, supra; Michel Foucault, Discipline and Punish: The Birth of a Prison (New York, NY: Vintage, 1977), [Foucault, 1977].

${ }^{56}$ Butler, supra note 5.

${ }^{57}$ Mary Jo Maynes, Jennifer L. Pierece, and Barbara Laslett eds, Telling Stories: The Use of Personal Narratives in the Social Sciences and History (New York, NY: Cornell University Press, 2008).
} 
epistemology and pedagogy allows for the creation of spaces in which the experience of subjectivity is challenged and examined. In particular, the way that our embodied being is positioned affects the experience of ourselves and our experience of others. Foucault states, "the prohibitions which regulate discourse determine who may speak and who may not and what conventions need to be employed". ${ }^{58}$ Feminist epistemology resists conventions that mute the voices of subjugated knowledges. This is taken up by Sneja Gunew as a way that Foucault lends to feminist theory. His work contributes to the understanding that the personal is political, "because power relations are sustained at every level".${ }^{59}$ The knowledge/power relations in university can be challenged at every level. Whether through discursive shifts via the use of standpoint theory or through feminist epistemologies that disrupt traditional conceptions of knowledge and how it is taught. ${ }^{60}$

\section{Standpoint Theory and Feminist Epistemology}

Standpoint theory became popular in the 1970s and 1980s. It was introduced as a feminist theory "about relations between the production of knowledge and practices of power" ${ }^{61}$ Standpoint theory is connected to feminist epistemologies. In particular, the discussion of knowledge as experience. There are varying conceptualizations of

\footnotetext{
${ }^{58}$ Gunew, supra note 12 at 19.

${ }^{59}$ Ibid at 22.

${ }^{60}$ Ibid; Meg Luxton \& Mary Jane Mossman eds, Reconsidering Knowledge: Feminism and the Academy (Canada: Fernwood Publishing, 2012).

${ }^{61}$ Sandra Harding, "Introduction: Standpoint Theory as a Site of Political, Philosophic, and Scientific Debate" in Sandra Harding ed, The Feminist Standpoint Theory Reader: Intellectual \& Political Controversies (New York: Routledge, 2004).
} 
experiential knowledge. It is also referred to as tacit knowledge, situated knowledge, and practical knowledge. As argued by Nancy Harstock, the goal of standpoint theory was to demonstrate that the lived experience of women offers a critique of patriarchal structures that permeate society. ${ }^{62}$ Complementing Hartstock's work, Dorothy E. Smith defines "tacit knowledge" as the knowledge that people gain from their daily lives. ${ }^{63}$ As two Socialist-Marxist Feminists, Smith and Harstock argue that in capitalist societies, the production of knowledge will be controlled by the ruling or dominant class. This has traditionally included men. ${ }^{64}$ Feminist standpoint theory seeks to thwart the reproductions of knowledges that exclude the experience of women and those who are marginalized.

Standpoint theory has remained controversial for its insistence on political engagement, but is committed to producing information that affects the lives of women. Moreover, standpoint theory remains critical of traditional Western research that remains "framed [by] commitments to bourgeois values, to white-supremacist, colonial, and imperial ways of thinking". ${ }^{65}$ Combating these traditions is also central to feminist pedagogies and feminist epistemology.

\footnotetext{
${ }^{62}$ Nancy Hartstock, The Feminist Standpoint Revisited and Other Essays (Boulder: Westview Press, 1998), [Hartstock, 1998]; "The Feminist Standpoint: Developing A Ground for a Specifically Feminist Historical Materialism" in Sandra Harding ed, The Feminist Standpoint Theory Reader: Intellectual \& Political Controversies (New York: Routledge, 2004), [Hartstock, 2004].

${ }^{63}$ Dorothy E. Smith, The Everyday World as Problematic: A Feminist Sociology of Knowledge (Boston, MA: Northeastern University Press, 1987).

${ }^{64}$ Hartstock, supra note 73; Smith, supra; Alison M. Jaggar, "Feminist Politics and Epistemology" in Sandra Harding ed, The Feminist Standpoint Theory Reader: Intellectual \& Political Controverises (New York, Routledge: 2004).

${ }^{65}$ Sandra Harding, "Standpoint Theories: Productively Controversial" (2009) Hypatia 192.
} 
Although feminist epistemology can be understood as having three distinct branches, feminist standpoint epistemology will be the focus of this literature review and thesis. Feminist standpoint epistemology accounts for knowledges that are gained from different experiences of oppression. ${ }^{66}$ Feminist epistemology cautions against the default that theory is only produced within the classroom. Notable feminist philosopher Lorraine Code is critical of the traditional understanding of knowledge as that which is inherited from positivism; the idea that pure, reason-based knowledge must be objective. ${ }^{67}$ The contributions of feminists to fields including philosophy "analysed how the absence of women in philosophical inquiry attested to and upheld significantly truncated presuppositions about human lives, practices, and values". ${ }^{68}$ Code suggests that women possess knowledge by virtue of their experience and position as women. This knowledge challenges the idea that knowledge must be objective and not produced from emotional or situated knowledges. ${ }^{69}$ Feminist epistemology has taken up an intersectional lens to account for the varying experiences of women as well as those who face additional forms of marginalization.

Situated Knowledges and Privilege

\footnotetext{
${ }^{66}$ Susan Archer Mann, Doing Feminist Theory: From Modernity to Postmodernity (New York: Oxford University Press, 2012) [Archer Mann].

${ }^{67}$ Lorraine Code, What Can She Know? Feminist Theory and the Construction of Knowledge (New York: Cornell University Press, 1991); "Ignorance, Injustice and the Politics of Knowledge: Feminist Epistemology Now" (2014) 29 Australian Feminist Studies 148.

${ }^{68}$ Supra.

${ }^{69}$ Ibid.
} 
Situated knowledges were the focus of both feminist standpoint epistemology and many feminist pedagogical theories. ${ }^{70}$ Feminist theory has also sought to elevate the voices of those who are marginalized. As explained by Meg Luxton, "feminism is both an intellectual project and a political movement, feminist academics were inevitably centrally involved in transforming knowledge production". ${ }^{71}$ This transformation has included the recognition of experiences as sites of knowledges, understood as situated knowledge. ${ }^{72}$ Knowledge traditionally understood as objective was, and continues to be, challenged by feminist academics. ${ }^{73}$ This perspective remains controversial within feminism itself. Smith is clear about not defining experience as a synonym for perspective: "accounting for direct experience becomes problematic when that is where the analysis begins and ends - it doesn't give the full picture". ${ }^{74}$ The positionality of standpoint theory is challenged by this idea.

In Alice Doesn't: Feminism, Semiotics, and Cinema, Teresa de Lauretis provides an understanding of experience that is integral to the reflexivity of feminist epistemology and standpoint theory, as well as the relational pedagogy advanced by this thesis. Lauretis clarifies:

\footnotetext{
${ }^{70}$ Gunew, supra note 12; Archer Mann supra note 77.

${ }^{71}$ Luxton, supra note 71.

${ }^{72}$ Luxton, ibid; Gunew, Archer Mann, ibid note 81.

${ }^{73}$ Ibid; Margaret Thornton, "Universities Upside Down: The Impact of New Knowledge Economy" in Meg Luxton \& Mary Jane Mossman eds, Reconsidering Knowledge: Feminism and the Academy (Canada: Fernwood Publishing, 2012).

${ }^{74}$ Dorothy E. Smith, "Women's Perspectives as a Radical Critique of Sociology" in Sandra Harding ed, The Feminist Standpoint Theory Reader: Intellectual \& Political Controversies (New York: Routledge, 2004).
} 
"by experience, I do not mean the mere registering of sensory data, or purely mental (psychological) relation to objects and events, or the acquisition of skills and competences by accumulation or repeated exposure. I use this term not in the individualist, idiosyncratic sense of something belonging to one and exclusively her own even though others might have 'similar experiences': but rather in the general sense of a process by which, for all social beings, subjectivity is constructed". ${ }^{75}$

De Lauretis argues that this is an on-going process. The way that we come to know ourselves and our subjectivity is not just through our own experience, but through an ongoing process of recognition. Our social relations are not individual but part of a continuous social and political history. ${ }^{76}$ This perspective is complemented by the work of Donna Harraway. Harraway explains the influx of attention to subjectivity as "selfinduced multiple personalities". ${ }^{77}$ On the one hand, "[feminists] unmasked the doctrines of objectivity because they threatened our budding sense of collective historical subjectivity and agency and our 'embodied' accounts of the truth" ${ }^{78}$ On the other hand, feminists also relied upon their own "semiotic technologies" ${ }^{79}$ The problem for

\footnotetext{
${ }^{75}$ Teresa De Lauretis, Alice Doesn't: Feminism, Semiotics, Cinema (United Kingdom: The Macmillan Press, 1984).

${ }^{76}$ Supra.

77 Donna Harraway; "Situated Knowledges: The Science in Question in Feminism and the Privilege of Partial Perspectives" in Sandra Harding ed, The Feminist Standpoint Theory Reader: Intellectual \& Political Controversies (New York: Routledge, 2004) 81-98 at 84.

${ }^{78}$ Supra.

${ }^{79} \mathrm{Ibid}$ at 85.
} 
Harraway is this paradox between "the relation of bodies and language". ${ }^{80}$ Although feminists sought to create an understanding of subjectivity that accounts for experience as embodied, they still relied upon textual engagements with this subjectivity.

Similarly, Uma Narayan is critical of this sort of feminist reading of subjectivity on the grounds that these ideas of feminist epistemology grant a certain "privilege" to those who are oppressed. Their experience with oppression grants them a form of insider knowledge that hinders open dialogue with those labelled as having (traditional) privilege ${ }^{81}$ Narayan is wary of the role that emotions play in our engagement with those whose experiences are different than our own. ${ }^{82}$ Building on these paradoxes of privilege, Pheobe Maltz Bovy explains that "the contemporary use of privilege emerged to address an absence in the language for discussing systemic inequality in general" ${ }^{83}$ While in scholarship it once meant "looking at oppression not only in terms of the oppressed, but also of the oppressor," it has become a buzzword lobbied at those who experience traditional markings of advantage. ${ }^{84}$ The idea behind the term "privilege" was to deconstruct the assumption that "a person is a forty-year-old-upper-middle-class white man, unless otherwise specified". ${ }^{85}$ Bovy does not suggest that trying to shift this assumption is a bad thing, but that "privilege" has become a behemoth term. This

\footnotetext{
${ }^{80} \mathrm{Ibid}$ at 81.

${ }^{81}$ Uma Narayan, "Working Together Across Difference: Some Considerations on Emotions and Political Practice" (1988) Hypatia 31.

${ }^{82}$ Supra.

${ }^{83}$ Pheobe Maltz Bovy, The Perils of Privilege: Why Injustice Can't Be Solved by Accusing Others of Advantage (New York: St. Martin's Press, 2017).

${ }^{84}$ Supra at 9.

${ }^{85}$ Ibid.
} 
understanding of privilege often results in emotionally-charged conversations that digress from political transformation. Narayan's perspective is important for understanding the way that varying experiences and emotions affect learning environments. The liberatory and feminist pedagogies discussed in the next session seek to create spaces where these dynamic (and often uncomfortable) discussions can take place.

\section{Pedagogy \& Practice}

\section{Traditional Pedagogy}

The institution of higher education was traditionally male-dominated. University was (and is) viewed as a place of liberalism, democracy, and enlightenment. ${ }^{86}$ These institutions were designed to teach men material that was written by men to go out and be part of a workforce that favoured men. The "experience, viewpoint, and goals of white, Western, elite males are taken as representing all human experience". ${ }^{87}$ As argued by Socialist-Marxist feminists like Smith and Hartstock, institutions of higher learner were part of the capitalist structure in which women's work was seen as less-than. Once women gained access to university there were still questions about how they could be taught and where they would go. ${ }^{88}$ The field of Women's Studies emerged out of this continued marginalization. This field has been adapted over the years to be more

\footnotetext{
${ }^{86}$ Frances Henry, Enakshi Dua, Carl E. James, Audrey Kobayashi, Peter Li, Howard Ramos, \& Malinda S. Smith, "The Equity Myth: Racialization and Indigeneity at Canadian Universities" (Canada: UBC Press, 2017).

${ }^{87}$ Frances A. Maher, "Toward A Richer Theory of Feminist Pedagogy: A Comparison of "Liberation" and "Gender" Models for Teaching and Learning" (1987) Journal of Education 91.

${ }^{88}$ Gunew, supra note 12; Luxton, supra note 71; Sandra Harding ed, The Feminist Standpoint Theory Reader: Intellectual \& Political Controversies (New York: Routledge, 2004).
} 
inclusive, and is generally known as Women's and Gender Studies. This discipline still exists within an institution that is rooted in patriarchal attitudes. Those within the field are often struggling with their role as activists, the goal of the discipline to remain engaged with a feminist politic, and their position within an academic setting that champions competitiveness, publishing, and a connection to the material that is not rooted in emotions. ${ }^{89}$

The traditional model of university education is one in which students are viewed as empty vessels. Professors are intended to fill them with information which is then regurgitated through papers and exams. This is often referred to as "the banking model". ${ }^{90}$ Gunew notes that this model produces and upholds particular kinds of knowledge: "knowledge could be described in territorial terms: knowledge as it has been legitimated within certain institutions, notably (but not only) the education system. Knowledge here becomes authorized learning to which only some have access". ${ }^{91}$ Law schools are institutions that teach the law as a form of this authorized knowledge. There is the view of the law and legal doctrine as the sole arbiter of truth. Students who identify with the subjugated knowledges as described by Foucault are often isolated within legal

\footnotetext{
${ }^{89}$ Supra.

${ }^{90}$ Paulo Freire, Pedagogy of the Oppressed: $30^{\text {th }}$ Anniversary Edition (New York: Bloomsbury, 2000); bell hooks, Teaching to Transgress: Education as the Practice of Freedom (New York, NY: Routledge, 1994), [hooks, 1994]; bell hooks, Teaching Community: A Pedagogy of Hope (New York: Routledge, 2003).

${ }^{91}$ Gunew, supra note 71 at 14.
} 
education. ${ }^{92}$ This isolation is remedied by theories of liberatory pedagogy that argue for the removal of cultural domination both within education and society as a whole. ${ }^{93}$

\section{Pedagogy of the Oppressed: Liberatory Pedagogy}

What is now called critical pedagogy was born out of the work of Paulo Freire. In his iconic text Pedagogy of the Oppressed, Freire outlines his theory of liberatory pedagogy. Heavily influenced by the work of Frantz Fanon, Paulo Freire calls for liberation that starts with those who are oppressed.${ }^{94}$ Freire calls on those who are oppressed to become aware of their oppression. Similar to the way that Fanon asks those who are oppressed to realize the ways in which their oppression has impacted their selfunderstanding, Freire advises the oppressed to realize the ways in which they have been dehumanized. This dehumanization has not only oppressed them, but it has dehumanized their oppressor; dehumanizing another kills what was human in the oppressor. ${ }^{95}$ For both Fanon and Freire, the oppressed must become aware of their position and its falsity. To be oppressed is not their natural state but a creation of those who have dehumanized them. This must be realized and understood in order to move forward with a liberatory pedagogy.

\footnotetext{
${ }^{92}$ Bhabha, supra note 25; Jasreet Badyal, "Perry v. Schwarzenegger: An Opportunity to 'Do' Law Differently" (2014) 19 Appeal: Review of Current Law and Law Reform 3; Elizabeth Sheehy \& Sheila McIntrye eds, Calling For Change: Women, Law, and the Legal Profession (Canada: University of Ottawa Press, 2006);

${ }^{93}$ Freire, supra note 101.

${ }^{94}$ Frantz Fanon, The Wretched of The Earth, translated by Richard Philcox (New York: Grove Press, 2004)

${ }^{95}$ Freire, ibid note 104.
} 
This pedagogy of the oppressed seeks to rebuild the narrative that is put forward by traditional pedagogy—students are empty vessels that the all-knowing teacher "fills" with knowledge. ${ }^{96}$ For Freire, the pedagogy of the oppressed must restore humanity through the dialogical process, "the fundamental goal of [which] is to create a process of learning and knowing that invariably involves theorizing about the experiences shared in the [process]. ${ }^{997}$ In this pedagogy, teaching must be transformative and not directive. This pedagogy has two stages. The first stage is where the oppressed expose the oppression that is occurring and uncover how they are being oppressed, and "through the praxis commit themselves to its transformation". ${ }^{98}$ In the second stage, this transformation has occurred and the pedagogy becomes not just of the oppressed but of everybody, in order to create lasting liberation. ${ }^{99}$ In both stages the culture of domination is confronted. ${ }^{100}$ This confrontation continues through a commitment to dialogical action and communication.

\section{Feminist Pedagogy}

What is missing from Freire's cultural confrontation is a gendered analysis. bell hooks addresses Freire's work in her book Teaching To Transgress: Education as the Practice of Freedom. While criticizing his "sexism and phallocentric paradigm of

\footnotetext{
${ }^{96}$ Freire, supra note 101 at 72.

${ }^{97}$ Ibid at 17.

${ }^{98}$ Ibid at 54.

${ }^{99}$ Ibid.

${ }^{100}$ Ibid.
} 
liberation" ${ }^{101}$, hooks encourages her reader to balance his theories of liberation with feminist thought and warns against creating the "binary opposition so common to Western thought". ${ }^{102}$ Her ability to acknowledge her criticisms of Freire's work while seeing its value is important to consider. hooks is cognizant of the complex relationships that occur both inside and outside of the classroom. While she does not agree with every aspect of Freire's theory, she remains open to its gifts and what feminist theorists can gain from it.

Freire and hooks are both critical of the traditional narrative of education in which professors give students information in a way that is touted as unbiased and removed. She challenges this by putting forward a pedagogy that acknowledges the student-teacher relationship as one that does not exist separate from the context of their own lives, experiences, and biases. Accordingly, teaching can never be politically neutral. ${ }^{103}$ For feminist pedagogy to create change there must be space for emotions and situational knowledge.

Emotions can be understood as embodied and socially constructed experiences. ${ }^{104}$ There are social standards for how emotions and responses should look in particular settings. Classrooms and lectures have their own standards for the place and conduct of emotional responses. This has been discussed throughout this literature review as the

\footnotetext{
${ }^{101}$ hooks, 1994, supra note 101 at 49.

102 Ibid.

${ }^{103}$ hooks, 1994, ibid at 30.

${ }^{104}$ Dale Spencer, Kevin Walby, \& Alan Hunt eds, Emotions Matter: A Relational Approach to Emotions (Canada: University of Toronto Press, 2012).
} 
result of the traditional pedagogies and theories of knowledge that post-secondary education was built upon. As part of feminist social practice, feminist pedagogy has its roots in reforming structures of patriarchy and marginalization. It has the goals of "consciousness-raising, social action, and social transformation". ${ }^{105}$ To achieve these goals, feminist pedagogy questions the traditional teaching method through "the ways that traditional knowledge production and received knowledge serve particular interests and social configurations of power". ${ }^{106}$ These configurations of power can be seen in Foucault's understanding of subjugated knowledges discussed earlier. Subjugated knowledges are ignored and excluded from the dominant understanding of knowledge. ${ }^{107}$

To advocate for these subjugated knowledges, feminist pedagogy "involves a critical examination of the academy itself as one of the power/knowledge institutions". ${ }^{108}$ It accounts for the "gendered character of the classroom" ${ }^{109}$ Linda Briskin explains that the first goal of feminist pedagogy is dismantling the contradictions experienced by feminist academics. These contradictions include: 1) the normative expectations presented to women in daily life that are brought into the classroom by students and teachers; 2) the normative expectations that women educators experience, especially feminist educators; and 3) the normative expectations that are experienced by women as

\footnotetext{
105 Robbin D. Crabtree, David Alan Sapp, \& Adela C. Licona eds, Feminist Pedagogy: Looking Back to Move Forward (Baltimore, MD: The Johns Hopkins University Press, 2004) at 4, [Crabtree, Sapp, \& Licona]. 
activists. ${ }^{110}$ The expectations and messages presented to women in these contradictions are: that motherhood is devalued while also being presented as the lifework of women; the reality of violence against women with the simultaneous ideology that men are the protectors of women; the stereotype that women are either attractive or intelligent and not both; the discrimination experienced in academia despite the fact that classrooms are presented as equal spaces; and the intersections of race and class bias. ${ }^{111}$

Briskin offers three strategies to negate these contradictions: teaching leadership, anti-sexism, and "reclaiming feminism in the classroom". ${ }^{112}$ The strategy of teaching leadership recognizes the expertise of the teacher without giving way to authoritarianism. This does not negate the experiences of students, and seeks to draw attention to power and inequality so that students can develop "an appreciation of collective power". ${ }^{113}$ Similarly, Briskin's anti-sexism strategy draws attention to gender in the classroom to raise consciousness and validate experience. It also aims to intersect issues of race and class with issues that relate to gender, all of which are present in the classroom. Briskin's last strategy, and the one she is adamant about, is bringing feminism back into the classroom. ${ }^{114}$ Following the feminist epistemologies presented above, feminist classrooms are those spaces which seek to make the invisible visible, and the subjugated

\footnotetext{
${ }^{110}$ Supra at 1.

111 Ibid.

112 Ibid.

${ }^{113}$ Ibid at 11.

${ }^{114}$ Ibid.
} 
liberated. ${ }^{115}$ Using these theories, I will explore the need and possibility for building feminist classrooms in this thesis. In particular, the ideas presented by feminist epistemologists, pedagogical theorists, and feminist relational theorists that I discuss below, will be used.

\section{Relational Theory \& Pedagogy}

Relational theory is described as focusing on the ways that relationships are "integral to self-understanding and to interactions with others at individual, collective, and even institutional levels". ${ }^{116}$ In this view, human beings are "constituted in and through relationships with others". ${ }^{117}$ Similarly, relational pedagogy views "education [as] a process of building relationships". ${ }^{118}$ The use of relational theory in critical pedagogy accounts for the situation of students as individuals with complex relationships that are socially embedded. This means that these relationships are impacted by webs of politics, socio-economics, race, gender, and class. ${ }^{119}$

Charles Bingham and Alexander Sidorkin explain that the continued existence of schools is not only because people need to learn, but "because education is primarily about human beings who need to meet together, as a group of people, if learning is to

\footnotetext{
115 Ibid at 19.

116 Jocelyn Downie and Jennifer L. Llewellyn eds, Being Relational: Reflections on Relational Theory and Health Law (Canada: UBC Press, 2012) at 4.

117 Supra.

118 Jane Pearce \& Barry Down, "Relational Pedagogy for Student Engagement and Success at University" (2011) Australian Council for Research in Education 483.

119 Kristina R. Llewellyn \& Jennifer J. Llewellyn, “A Restorative Approach to Learning: Relational Theory as Feminist Pedagogy in Universities" in Tracy Penny Light, Jane Nicholas, \& Renée Bondy eds, Feminist Pedagogy in Higher Education: Critical Theory and Practice (Canada: Wilfrid Laurier University Press, 2015) [Llewellyn \& Llewellyn].
} 
take place". ${ }^{120}$ Building on this work, Kristin Hunt explains relational pedagogy as predicated on the social component of the classroom: "the social environment of the classroom exists prior to and takes priority over any specific learning objective pursued within a classroom space". ${ }^{121}$ Regardless of the pedagogical approach, classrooms exist as social spaces in which communication of some form will take place.

Communication and access are key aspects to the functioning of relational pedagogy. ${ }^{122}$ In a study of 16 undergraduate students, Jane Pearce and Barry Down found that the relationships between students and academics were more positive where interaction with students was encouraged "whether in lectures, tutorials or in conversations outside class times". ${ }^{123}$ When students were able to engage individually with professors, there was a positive effect on their learning experience. ${ }^{124}$ Where there was poor communication, students noted that it felt "just like banging your head against a brick wall". ${ }^{125}$ Communication within the classroom should also be participatory. Participatory communication "is the making of something in common" and should result in a "shared understanding". ${ }^{126}$ This runs counter to the traditional banking-model of education in which students are treated as not possessing their own side of the conversation.

\footnotetext{
${ }^{120}$ Charles Bingham and Alexander M. Sidorkin ed, No Education Without Relation (New York: Peter Lang, 2004) at 5.

${ }^{121}$ Kristin Hunt, "Classroom Cons and Assigning Activism: Ethical Issues in Relational Pedagogy" (2015)

25 Theatre Topics 199 at 201.

122 Supra note 129.

${ }^{123}$ Supra at 486.

124 Ibid.

${ }^{125}$ Ibid at 487.

${ }^{126}$ Ibid.
} 
Jennifer J. Llewellyn and Kristina R. Llewellyn argue for a pedagogical approach that not only acknowledges that both students and teachers exist in contexts that are not unbiased and sanitized as traditional pedagogy would presume, but relies on relational theory to take this context into the complex web of relationships that students, teachers, and institutions are a part of. ${ }^{127}$ According to Llewellyn and Llewellyn, relational theory must be feminist relational theory, which "affirms the significance of the fact of relationship and signals the importance of attending to what is required within relationship to ensure well-being and flourishing". ${ }^{128}$ The classroom relationship is one such relationship that contributes to both the bolstering and/or diminishment of particular voices. In the following chapter, I will provide a more in-depth look at critical and relational pedagogies. This discussion will advocate for the use of relational theory in combination with feminist pedagogies and feminist epistemologies.

\footnotetext{
${ }^{127}$ Supra.

${ }^{128} \mathrm{Ibid}$ at 17.
} 


\section{Chapter 3: Pedagogy and Practice}

\section{Introduction}

Paulo Freire is considered to be the leading theorist of liberatory or critical pedagogy. His 1968 book, The Pedagogy of the Oppressed, serves as the backbone for most contemporary critical pedagogies. His work reflects the post-colonial theory of Frantz Fanon but without the focus on violence and uprising. ${ }^{129}$ Instead, the liberation presented by Freire is one that begins with education. Taking up the contributions of Freire, bell hooks provides a theory of pedagogy that focuses on feminism, intersectionality, and situated knowledge. In both of these accounts, the focus is on consciousness-raising and transforming society. Similarly, feminist relational theorists have contributed methods of relational education as a form of critical pedagogy, that appreciates situated knowledge as part of our relationships with one another and to the contexts in which we live.

In addition to using these pedagogical methods, my analysis will focus on the emotional and affective responses that can arise in classroom contexts. Regardless of what approach is used in a classroom, the university is a social environment which can cause varying anxieties for both students and professors. When the subject-matter is oppression and/or violence these emotional reactions can be particularly visceral. These emotional experiences will be discussed in combination with the complexities of privilege and the ways that privilege(s) affect the ways we respond to one another. I will

\footnotetext{
${ }^{129}$ Paulo Freire, Pedagogy of the Oppressed: $30^{\text {th }}$ Anniversary Edition (New York: Bloomsbury, 2000); Frantz Fanon, Wretched of the Earth, translated by Richard Philcox (New York: Grove Press, 2004).
} 
also account for my position as a person with traditional markings of privilege (white, cisgender, middle-class) and what that means for my experiences of abuse and their translation to classroom discussion.

This chapter will begin with a brief discussion on the inequalities in Canadian law schools. It will focus on those who are 'othered' or oppressed, and how that translates into experiences in the classroom. From there, the theories provided by Paulo Freire and bell hooks will be discussed. These accounts will lead into a discussion of the attempt to create contextual understanding through experiential education (EE) or community legal services (CLS) models. These models are aimed at social justice and combining classroom knowledge with experience. However, I argue that their lack of commitment to a relational approach creates gaps in the effectiveness of their approach.

Inequality in Canadian Law Schools: Gender, Race, and Indigeneity

In 1993, the Canadian Bar Association released the 328-page report Touchstones

for Change: Equality, Diversity, and Accountability-A Report on Gender Equality in the Legal Profession. This report not only touched on gender bias in the formal practice of law and barriers to equality in the profession, but also on the gender-bias in law schools and the barriers to equality for admission to law school. ${ }^{130}$ Twenty-four years later this inequality persists. Sanda Rodgers explains that institutions of legal education in Canada uphold and reproduce gender inequality while continuing to disregard the existence of

\footnotetext{
${ }^{130}$ Canadian Bar Association, Touchstones for Change: Equality, Diversity, and Accountability-A Report on Gender Equality in the Legal Profession (Ottawa, ON: Canadian Bar Association, 1993).
} 
privilege and elitism within their walls. ${ }^{131}$ She argues for the feminist administration of law schools which would require true dedication to the eradication of social inequalities, and a continued acknowledgment of the role of law in these inequalities; as well as the role of legal education in dismantling them. ${ }^{132}$ Roberick Macdonald and Thomas McMorrow described law school as formed within the colonial project: "we believe that the legal education established in Canada has been and remains thoroughly dominated by powerful exogenous forces in a manner that can be analogized to colonization". ${ }^{133}$ This is reflected in Sheila Cote-Meek's work in her book Colonized Classrooms: Racism, Trauma and Resistance in Post-Secondary Education. Cote-Meek argues that the experience of indigenous persons in the classroom is often difficult and they do not feel the same liberty to speak as their classmates. ${ }^{134}$ She explains, "the space of the classroom, what is transmitted in that space and the relationships that occur in that space are all affected by the longstanding and ongoing colonial and imperial practices". ${ }^{135}$ We are all affected by the world that exists outside of the classroom, and that world impacts what happens inside the classroom. This is particularly poignant for students and instructors who are 'othered' or marginalized.

\footnotetext{
${ }^{131}$ Sanda Rodgers, "Educating for Equality: The Meaning of Feminist Administration for Legal Education in Canada" in Elizabeth Sheehy \& Sheila McIntyre eds., Calling for Change: Women, Law, and the Legal Profession (Ottawa, ON: University of Ottawa Press, 2006)

132 Ibid at 152 .

${ }^{133}$ Roderick A. Macdonald \& Thomas B. McMorrow, "Decolonizing Law School" (Paper delivered at the Future of Law School Conference, University of Alberta September 2013) at 3.

${ }^{134}$ Sheila Cote-Meek, Colonized Classrooms: Racism, Trauma and Resistance in Post-Secondary Education (Canada: Fernwood Publishing, 2014).

135 Supra at 91.
} 
While universities appear to be progressive institutions, indigenous and racialized professors and students are often faced with hostility. ${ }^{136}$ Similarly, feminist academics are often expected to conform to more traditional methods and practices. Male-dominated ways of doing academia are exclusionary and often condescending towards feminist scholarship. ${ }^{137}$ As a result, feminist academics walk a difficult line between their political practice as feminists and their ability to stay in the academy to do work they find meaningful. ${ }^{138}$ Leighann Burns and Zara Suleman created a guide to help students survive law school as an "anti-colonial, anti-racist, feminist activist". ${ }^{139}$ Their tips include bringing in outside materials to critique the readings and cases provided, particularly feminist, queer, critical race, and intersectional theory. ${ }^{140}$ Additionally, they stress that situated knowledge should be taken as part of the discussion, stating "the lived experiences for those who are 'othered' will provide critical context for the cases read for class and will provide equality-seeking students with the tools to speak up and defend their positions". ${ }^{141}$ These tips are not only crucial to the study of law but for the ability of students to survive law school.

\footnotetext{
${ }^{136}$ Frances Henry, Enakshi Dua, Carl E. James, Aubrey Kobayashi, Peter Li, Howard Ramos, \& Malinda S. Smith, The Equity Myth: Racialization and Indigeneity at Canadian Universities (Canada: UBC Press, 2017).

${ }^{137}$ Rogers, supra note 3; Meg Luxton \& Mary Jane Mossman eds., Reconsidering Knowledge: Feminism and the Academy (Canada: Fernwood Publishing, 2012); Sneja Gunew, Feminist Knowledge: Critique and Construct (New York: Routledge, 1990).

${ }^{138}$ Luxton \& Mossman, supra.

${ }^{139}$ Leighmann Burns and Zara Suleman, "Justicia In Your Face: How to Surive Law as An Anti-Colonial, Anti-Racist, Feminist Activist" in Elizabeth Sheehy \& Sheila McIntrye eds, Calling For Change: Women, Law, and the Legal Profession (Canada: University of Ottawa Press, 2006).

${ }^{140}$ Supra at 143.

${ }^{141}$ Ibid.
} 
One way to change how university is experienced is to change how it is taught. Paulo Freire's Pedagogy of the Oppressed, as well as his other pedagogical work, focuses on education as the vehicle by which social transformation can occur. ${ }^{142}$ The liberatory pedagogy he creates has been built upon by feminist, critical, and relational theorists alike. These theories should serve as the building-blocks for changing Canadian legal education (and by extension, Canadian legal practice).

\section{Paulo Freire: Building Liberatory Pedagogy}

\section{A Note on Epoch and Praxis}

Law schools can serve as an example of what Paulo Freire calls epoch:

"An epoch is characterized by a complex of ideas, concepts, hopes, doubts, values, and challenges in dialectical interaction with their opposites, striving towards plenitude. The concrete representation of many of these ideas, values, concepts and hopes, as well as the obstacles which impeded the people's full humanization, constitute themes of that epoch. These themes imply others which are opposing or even antithetical; they also indicate tasks to be carried out and fulfilled. Thus, historical themes are never isolated independent, disconnected, or static; they are always interacting dialogically with their opposites". ${ }^{143}$

\footnotetext{
${ }^{142}$ Freire, supra note 1.

${ }^{143}$ Ibid at 101.
} 
The experience of those who come to legal education from positions of marginalization can be understood in this way. As I have discussed, law schools are inherently linked with structures of colonialism, imperialism, and domination. The competitive environment of university encourages students to see one another as opposites, interacting in a way that escapes dialogical process and reflection. Freire explains that the fundamental theme of this epoch is that of domination, which makes liberation the goal of a pedagogy of the oppressed. ${ }^{144}$ This liberation occurs through praxis, described by Freire as "reflection and action directed at the structures to be transformed". ${ }^{145}$ This praxis can be created through liberatory pedagogy that centres around dialogue. For dialogue to be meaningful, it "cannot exist between those who wish to name the world as it really is and those who deny them the right to speak". ${ }^{146}$ For example, those who wish to expose the reality of gender-based violence and those who try to dismiss the issue as only occurring because of a few individuals. Understood in this way, dialogue is not simply a communication of words but a communication of reflection and action. ${ }^{147}$

\section{'Conscientizacao' and Dialogue}

Dialogue and consciousness-raising are integral components of the implementation of the pedagogy of the oppressed. If the dialogical process of this pedagogy is translated into a specific method, then it loses its value. ${ }^{148}$ Instead, Freire argues that dialogical teaching must be an on-going process. The fundamental goal of

\footnotetext{
${ }^{144}$ Supra.

${ }^{145}$ Ibid at 126.

${ }^{146}$ Ibid at 87.

${ }^{147}$ Ibid.

${ }^{148}$ Supra.
} 
Freire's pedagogy of the oppressed is "to create a process of learning and knowing that invariably involves theorizing about the experiences shared in the dialogue process". ${ }^{149}$ This is counter to the traditional "banking-model" of education. The banking-model views students not as people will complex lives, experiences, and relationships; but as objective, almost disembodied, audience members. This model is based on the idea that "memorizing information and regurgitating it [represents] knowledge". ${ }^{150}$ The 'knowledge' referred to in the banking-model is knowledge rooted in Western systems of colonialism and patriarchy. ${ }^{151}$

For this knowledge to be challenged, it is paramount that the pedagogy of the oppressed not be "an emulation of how the oppressed should be from the oppressors". 152 Nor is it the replacement of one system of oppression by another. Instead, the goal of this pedagogy is liberation, not just for the oppressed but for all of society. Freire outlines a two-stage process for liberation through his pedagogy, both of which contribute to confronting the culture of domination. ${ }^{153}$ In the first stage, "the oppressed unveil the world of oppression and through praxis commit themselves to its transformation". ${ }^{154}$ By changing their view of oppression, the oppressed confront this domination. They are able to see the way that they have been taught to believe their oppression as inherent instead

\footnotetext{
149 Ibid at 17.

150 bell hooks, Teaching to Transgress: Education as the Practice of Freedom (New York, NY: Routledge, 1994).

${ }^{151}$ Freire, supra note 1; hooks, supra; Cote-Meek, supra note 6.

152 Freire, ibid at 54.

${ }^{153}$ Ibid.

154 Supra at 54.
} 
of manufactured. The second stage occurs when this transformation has already occurred, where "this pedagogy ceases to belong to the oppressed and becomes a pedagogy of all people in the process of permanent liberation". ${ }^{155}$ This stage confronts the culture of domination by expelling the myths of oppression that would prevent revolution. ${ }^{156}$ It is unsurprising that Paulo Freire explains his point of view as "that of the "wretched of the earth" given the similarly between these stages and the work of Frantz Fanon. ${ }^{157}$ This connection is reflected in what Freire calls conscientizacao or 'conscientization'. 158

Conscientization refers to the process by which the oppressed become aware of their oppression, imbuing the oppressed with a critical consciousness. This critical consciousness is crucial to the success of these pedagogical stages and lasting liberation. The continuation of oppression relies on the domination over the truth by the oppressor. Freire argues that the truth of the world is put into power through words and dialogue. This dialogical process of the pedagogy of the oppressed requires that dialogue be ongoing. As such, the student-teacher relationship can no longer be predicated on the "banking model" but must instead be a "problem-posing" model. ${ }^{159}$ In problem-posing education, students are in a cooperative dialogue with teachers and fellow students, which acknowledges the version of the world that has been presented to the oppressed. This

\footnotetext{
155 Ibid.

156 Ibid.

${ }^{157}$ Paulo Freire Pedagogy of Freedom: Ethics, Democracy, and Civic Courage (Maryland: Rowan \& Littlefield Publishers, 1998).

158 Supra.

${ }^{159}$ Freire, supra note 1 at 81.
} 
version of the world presents the oppression experienced by the marginalized and oppressed as truth, rather than as a limited reality that be overcome and transformed. ${ }^{160}$ The idea of problem-posing education is that "people develop their power to perceive critically the way they exist in the world with which and in which they find themselves; they come to see the world not as a static reality, but as a reality in process, in transformation" ${ }^{161}$ That is, students must be taught in a way that accounts for their experiences outside of classroom. This relational component requires students to move past theoretical discussion and continue liberatory dialogue that connects their lived experiences with the transformative possibilities for eliminating their oppression. Freire states:

"[s]tudents, as they are increasingly posed with problems relating to themselves in the world and with the world, will feel increasingly challenged and obliged to respond to that challenge. Because they apprehend the challenge as interrelated to other problems within a total context, not as theoretical questions, the resulting comprehension tends to be increasingly critical and thus constantly less alienated. Their response to the challenge evokes new challenges, followed by new understandings; and gradually the students come to regard themselves as committed" ${ }^{162}$

\footnotetext{
${ }^{160} \mathrm{Ibid}$.

${ }^{161}$ Ibid at 83.

162 Ibid at 81.
} 
This commitment occurs through the dialogue that continues as praxis. The challenges to dialogue and conscientizacao as praxis are conquest, division and rule, and cultural invasion. These themes are central to antidialogical action, in which the oppressed is turned into an object. ${ }^{163}$ Freire explains that "antidialogue is necessary to the oppressor as a means of further oppression". ${ }^{164}$ Antidialogical action includes the maintenance of separation among the oppressed as well as the continued dismissal of their culture. ${ }^{165}$ This is why conscientization is so crucial for the pedagogy of the oppressed to succeedif liberation is to be lasting and meaningful, the oppressed need to become aware of the ways that they are dominated. Otherwise the continued division and invasion can occur. Education is a site for liberation because it allows for a collective conscientization. The pedagogy of the oppressed must include dialogue with the oppressed, otherwise the same system of domination will return and liberation will not last. ${ }^{166}$

The dialogical process so key to Freire's theory undercuts the methods of domination encouraged by the banking-model of education. In this traditional model, students are not instructed to position themselves within the content being taught. Instead, students are necessarily positioned as pedagogically subordinate. This position of students as subordinate prevents the oppressed students from reaching conscientizacao by convincing them of "their intrinsic inferiority" ${ }^{167}$ However, this processes of

\footnotetext{
${ }^{163}$ Freire, supra note 1.

164 Ibid at 138.

165 Ibid.

${ }^{166}$ Ibid.

${ }^{167}$ Ibid at 153.
} 
antidialogical action can be challenged through education. Students can become aware of their positionality within the world and their connection to others in order to engage in meaningful, liberatory dialogue. This process is explored further by feminist theorists who seek to apply a gendered analysis to the experience of institutionalized oppression. Feminist and Relational Pedagogy

bell hooks

Feminist pedagogy expands on the liberatory method proposed by Freire. ${ }^{168}$ bell hooks offers an important contribution to the continuation of critical pedagogy through her analysis of Freire's shortcomings and her production of feminist theory. In Teaching to Transgress, hooks addresses Freire's work, explaining: “to have a work that promotes one's liberation is such a powerful gift that it does not matter so much if the gift is flawed". ${ }^{169}$ The flaw to which hooks refers is the lack of gendered intersections in Pedagogy of The Oppressed. Freire speaks only of oppression from assumption of the oppressed individual as man. While he makes reference to the interactions of men and women, Freire does not acknowledge the particular models of oppression experienced by women. ${ }^{170}$ bell hooks creates an opportunity to examine the ways that feminist theory can contribute to building critical classrooms as well as the ways that feminist theory must be reflexive.

\footnotetext{
${ }^{168}$ Kathleen Weiler, "Rereading Paulo Freire" in Kathleen Weiler eds, Feminist Engagements: Reading, Resisting, and Revisioning Male Theorists in Education and Cultural Studies (New York, NY: Routledge, 2001).

${ }^{169}$ hooks, supra note 21 at 50.

${ }^{170} \mathrm{Ibid}$; Freire, supra note 1.
} 
The position advanced by hooks is that classrooms are communal spaces where each person must be acknowledged. This acknowledgement requires an intersectional and culturally diverse approach which accounts for the experiences of students as legitimate sources of knowledge. ${ }^{171}$ Students must be able to question why material does not engage with praxis (whether feminist or otherwise), and critical pedagogy "[ [... must embrace experience, confessions and testimony as relevant ways of knowing, as important, vital dimensions of any learning process". ${ }^{172}$ Moreover, educational practices must not take for granted the interest of students to produce community and cooperation. According to hooks, those who experience oppression do offer a unique standpoint from which to critique oppression. However, the possession of this unique standpoint does not mean that it can be their only location of analysis. hooks is adamant that multiple sites of knowledge and analysis should be accepted and encouraged in order to engage with material more fully. ${ }^{173}$ This also means that the perspectives of those who are oppressed should not be dismissed. For example, hooks focuses much of her work on the experiences of black women within feminist theory and Women's Studies, two fields that have been traditionally dominated by white women. hooks is critical of the reproduction of feminist theory that does not encourage an intersectional lens. Therefore, for hooks, liberatory pedagogy must be a collective, cooperative, and intersectional act.

\footnotetext{
171 hooks, supra note 21.

${ }^{172}$ Ibid at 89; bell hooks, Teaching Community: A Pedagogy of Hope (New York: Routledge, 2003).

${ }^{173}$ Supra.
} 
Critical pedagogy must strive to create "a context where we can engage in open critical dialogue with one another, where we can debate and discuss without fear of emotional collapse, where we can hear and know one another in the difference and the complexities of our experience". ${ }^{174}$ Where Freire's discussion of how the oppressed's conscientization of their own oppression cab be painted as false through antidialogical methods, hooks's focus on the importance of the oppressed's situated knowledge means that we cannot separate or dismiss their perspectives from the practice of critical pedagogy. To do so would fall into the antidialogical action of conquest, division, and invasion. ${ }^{175}$ The perspectives of those who have been marginalized must be taken seriously in the practice of critical pedagogy. This means that professors should expect students to be able to share their experiences, act responsibly, and that all participants should feel empowered through their education. This does not mean ignoring the power dynamics in classroom environments but understanding and being aware that they are present through all our interactions. ${ }^{176}$

Relationality \& The Limitations of Experiential Education and Community Service Learning

Experiential education (EE) or community service learning (CSL) are ways to give students personal experience to highlight what they have learned in the

\footnotetext{
174 hooks, supra note 21 at 110.

${ }^{175}$ Freire, supra note 1.

${ }^{176}$ hooks, supra note 21; supra note 43.
} 
classroom. ${ }^{177}$. These models have become increasingly popular in Canadian law schools. They may take the form of legal clinic placements, externships, and internships. While these models are intended to put what has been learned in the classroom into context, they fall short of that goal when the classroom information is grounded in traditional pedagogy.

Shin Imai, Associate Professor at Osgoode Hall, utilizes his experience as a law student, lawyer, and professor, to argue for a more progressive and holistic approach to experiential learning. Imai is critical of the idea that students can immediately translate what they have learned into a given community, particularly without context and a nuanced understanding of the community being served. ${ }^{178}$ His analysis focuses on his own experience as a lawyer in the indigenous community in Moosonee, and the ways that his legal education served him for some roles and not others. He was well equipped to handle the traditional office work involved with lawyering, but when it came to his role in the community he was not prepared. He explains:

"I learned that conventional legal tools such as negotiation or litigation were not enough. Community organizing, media releases, demonstrations and road blockades were all ways of addressing 'legal problems, and lawyers could play different supportive roles depending the strategy

\footnotetext{
${ }^{177}$ Linda Briskin, "Activist Feminist Pedagogy: Privileging Agency in Trouble Times" in Tracey Penny Light, Jane Nicholas, \& Renée Bondy eds., Feminist Pedagogy in Higher Education: Critical Theory and Practice (Canada: Wilfrid Laurier University Press, 2015).

${ }^{178}$ Shin Imai, "A Counter-Pedagogy for Social Justice: Core Skills for Community-Based Lawyering” (2002) 9 Clinical Law Review 195.
} 
chosen. For these non-conventional roles, the lawyering skills learned at law school were at best of no-assistance, and at worst, quite harmful." 179 This type of community-lawyering has a social justice objective but the skills reproduced by legal education do not meet this end. ${ }^{180}$ Linda Briskin cautions that EE or CSL models can contribute to the individualization of social problems. The experiences provided by these models can cause stereotypes toward marginalized communities to be reaffirmed, and can result in students feeling pity towards the communities they are serving. ${ }^{181}$ If we are going to talk about issues of social justice in a critical way, then the right pedagogical tools need to be used; law students need to see and feel the relational aspect of their field of study.

Christine Koggel explains relational theory as having several features. First, there is an examination of relationships and how they are shaped by social, global, and historical contexts. Second, relational theory aims to reveal "the norms, standards, and practices that are in place" and must be responded to. Finally, that the perspectives of those who are oppressed "are important vantage points for understanding inequalities and what is needed to remove them". ${ }^{182}$ Building on the work of liberatory pedagogy, feminist pedagogy, and relational theory, Kristina R. Llewellyn and Jennifer J. Llewellyn argue for a relational feminist pedagogy. Llewellyn and Llewellyn's approach also

\footnotetext{
179 Supra at 196.

180 Ibid.

${ }^{181}$ Briskin, supra note 48.

182 Christine M. Koggel, “A Relational Approach to Equality” in Jocelyn Downie and Jennifer L. Llewelyn eds, Being Relational: Reflections on Relational Theory and Health Law (Canada: UBC Press, 2012).
} 
centres around dialogue: it is "a process of dialogue that includes non-verbal communication". ${ }^{183}$ They argue for the right of those with "intimate knowledge of the context" to be considered. ${ }^{184}$ This recognition of situated knowledge would mean an important acknowledgement of who is at risk, and what that means for the experience of the oppressed in the classroom. If we take for example a course on the subject of genderbased violence, it would be naïve to assume that students in that space are not aware of this subject-matter outside of the classroom. Given the rates of gender-based violence in Canada, it is likely that one or more students within that space have been assaulted, abused, or harassed. To teach this subject in an objective way would be disingenuous and antithetical to the complex webs of social relationships that form and shape the lives of students.

Pearce and Brown caution that "when academics do not recognize the potentially exclusionary impact of their pedagogies and thus fail to engage in a relationship that can provide support when it is needed, they may unconsciously perpetuate existing social inequalities". ${ }^{185}$ To overcome this possibility, a relational or restorative approach would focus on the relationships that "transcend the multiple one-on-one encounters in the classroom". ${ }^{186}$ This does not mean a simple acknowledgement that these relationships

\footnotetext{
${ }^{183}$ Kristina R. Llewellyn \& Jennifer J. Llewellyn, “A Restorative Approach to Learning: Relational Theory as Feminist Pedagogy in Universities" in Tracy Penny Light, Jane Nicholas, \& Renée Bondy eds., Feminist Pedagogy in Higher Education: Critical Theory and Practice (Canada: Wilfrid Laurier University Press, 2015) at 21-22.

${ }^{184}$ Supra at 20.

${ }^{185}$ Jane Pearce \& Barry Down, "Relational Pedagogy for Student Engagement and Success at University" (2011) Australian Council for Research in Education 483 at 492.

${ }^{186}$ Llewellyn \& Llewellyn, supra note 5419.
} 
exist, but a deeper recognition of how they impact our understanding of the world and of ourselves. This means any issue — social, political, legal or otherwise — cannot be discussed without "attention to its causes, contexts, and implications". ${ }^{187}$ A relational approach would require that knowledge be understood as fluid and dynamic: "the experiences, needs, and perspectives of all learners, including educators, matter and are central, not in contract to or in competition with one another, but in relation to one another". ${ }^{188}$ If a classroom environment is founded upon a relational approach, space is created for cooperative and responsible dialogue that moves past the textual focus of traditional pedagogy.

To account for the relational aspects of learning and knowing in pedagogy means paying attention to the experiences of students and the responses that those experiences yield. Relational pedagogy does not mean that those who have experiences can usurp discussion or are the only ones who should speak, but that the acknowledgement of those experiences is paramount to a continued dialogical process of knowing. Students must be able to relate to one another, and to the world outside of the classroom, in order to understand course material in the context of real-world experiences and relations.

Conflicts, Feelings, and Conflicting Feelings

Embodied Emotions and Affective Responses

\footnotetext{
187 Ibid at 22.
}

${ }^{188} \mathrm{Ibid}$ at 19. 
Liberatory pedagogy is of the view that those who experience marginalization are seen by educational institutions as "generally emotional, instinctual, and best handled by being subdued by the superior powers of reason". ${ }^{189}$ Thus the focus of liberatory pedagogy on raising situated knowledges and acknowledging the embodied experiences of oppression, both within the classroom and outside of it, is paramount. Given the focus of situated knowledge in the critical pedagogies I have discussed, it is likely that they will create visceral responses as much as they create spaces to discusses them. The theories presented in this chapter do not view the emotions that come with situated knowledge as faults or as antithetical to the goals of learning. bell hooks in particular speaks of teaching as an act of love. ${ }^{190}$ Her experiences with pain and healing are part of what drives her theory - the experiences and emotions that are felt as part of daily life are not left at the classroom's door. ${ }^{191}$

As explained by Carrolyn Pedwell and Whitehead Anne, "the work of oppression is often carried out at an affective level" ${ }^{192}$. Understood in this way, affect is more than just an emotional response, but is a visceral reaction to different discursive and textual realities. ${ }^{193}$ For Pedwell and Whitehead, this means that "affect [cannot] be deduced to either 'discourse' or 'emotion', but rather exceeds these categories; it is a material

\footnotetext{
${ }^{189}$ Frances A. Maher, “Toward a Richer Theory of Feminist Pedagogy: A Comparison of 'Liberation' and 'Gender Models for Teaching and Learning” (1987) 169 Journal of Education 91.

${ }^{190}$ hooks, supra note 21; supra note 43.

${ }^{191}$ Ibid.

${ }^{192}$ Carolyn Pedwell and Anne Whitehead, "Affecting Feminism: Questions of Feeling in Feminist Theory" (2012) 13 Feminist Theory 115.

${ }^{193}$ Supra.
} 
intensity that emerges via the 'in-between' spaces of embodied encounters". ${ }^{194}$

Classrooms are inherently spaces of embodied encounters, whether or not the pedagogy used is a critical one. Both students and professor are embodied beings and are likely to have affective responses to content and discussion. ${ }^{195}$ This understanding of affect can be understood as relating to the presentation of emotions as embodied, social experiences. ${ }^{196}$ Whether or not they are explicitly acknowledged through course material or method, they will exist.

Reflecting on his experience as a professor, David Lewkowich laments his anxiety and his "sweaty pedagogical self". ${ }^{197}$ He provides an insight into the affective (sweat) and emotional (anxiety) responses of an educator, admitting: "since I've always had my own issues with embodiments of authority, as a professor, I think that I want to appear as approachable and flawed, and if I'm a sweaty mess, and standing on display as the sprinklings of a fault spigot, I can certainly claim that, at the very least, I have made myself into a kind of vulnerable subject". ${ }^{198}$ Similarly, Jack Katz makes references to the role of emotions for the lecturer: "[e]motions and feelings are ways of grasping, appreciating, and corporeally reflecting on the very structuring of life into social forms. Lecturers' emotions emerge as they realize aspects of the in-class situated structuring of

\footnotetext{
194 Ibid at 116.

195 David Lewkowich, "Reminders of the Abject in Teaching: Psychoanalytical Notes on my Sweaty, Pedagogical Self” 16 Emotion, Space, and Society 41.

196 Dale Spencer, Kevin Walby, \& Alan Hunt eds., Emotions Matter: A Relational Approach to Emotions (Canada: University of Toronto Press, 2012).

197 Supra note 28.

${ }^{198}$ Ibid at 43.
} 
their behaviour that the audience cannot know". ${ }^{199}$ For Lewkowich, this un-knowable information is the opposite of the image that he wants to project to his students.

Grappling with these conflicting feelings results in the hyper-visible affective response of excessive perspiration.

As a student, I was never aware of whether or not my professors were experiencing anxiety, perhaps distracted by my own affective and emotional responses (and my own sweat). Yet every day of my academic life I have feared that I would cry in a seminar or a lecture. To be in traditional academic spaces often means to put on a performance in which your emotional and affective responses are smothered. If sweat and tears are affective and emotional responses to the structures and spaces of lectures and seminars, what about the emotional responses that result from the focus on situated knowledge in critical pedagogy?

\section{Paradoxes of Privilege and Situated Knowledges}

The acknowledgement of oppressed voices means the continued use of situated knowledges. For Freire, the knowledge of oppression helps the oppressed achieve conscientization; in the pedagogy advanced by bell hooks, situated knowledges must be taken in combination with other sources of knowledge; and in a relational approach these knowledges must be understood in relational to one another and the world. Jill Stauffer explains that "[s]elves are formed intersubjectively, in the presence of others, for better

\footnotetext{
${ }^{199}$ Spencer, Walby, \& Hunt, supra note 67 at 18.
} 
and worse and regardless of whether any of us would have willed it to be this way". ${ }^{200}$ Education is one way that we enter into this experience.

Uma Narayan is critical of the use of emotions in political communication because of their limitations. ${ }^{201}$ These spaces become filled with accusations of misunderstanding and privilege, often overlooking the subject-matter and creating hostility. If critical pedagogies are reliant upon the situated knowledges of students, what about situated knowledges of those who are part of the population understood as the oppressor or colonizer, i.e. white, middle-class students? Narayan cautions that the discomfort of well-intentioned privileged — or oppressive - persons is not easily overcome by goodwill or good intentions. She explains that "the advantaged would be wrong to expect this to be sufficient to cause strong, historically constituted networks of distrust to simply evaporate into thin air". ${ }^{202}$ It would be naïve to assume that even when critical pedagogies are used students' discussions will be free of distrust as a result of oppressive power relations. This distrust is understandable.

I benefit from many trappings of privilege - I am white, cis-gender, and middleclass - but I am also a person who has experienced emotional abuse. When I am in classroom environments where issues of gender and violence are discussed, I am instinctively uncomfortable. I have been in spaces where the subject of psychological

\footnotetext{
${ }^{200}$ Jill Stauffer, Ethical Loneliness: The Injustice of Not Being Heard (New York: Columbia University Press, 2015) at 5.

${ }^{201}$ Uma Narayan, "Working Together Across Difference: Some Considerations on Emotions and Political Practice" (1988) Hypatia 31.

202 Supra at 34.
} 
abuse as a form of domestic violence has surfaced and not known whether I would raise my voice and explain my experience. A relational approach could account for this discomfort by acknowledging that the relationships between us and our subject-matter are important. Moreover, a relational pedagogy acknowledges that the subjects we discussed are not removed from their social and political context simply because a classroom is removed.

However, if a student were to voice their situated experience, even in a relational context, it does not mean that they would be granted a free pass. It does not mean that they have all the answers or are exempt from drawing further analysis. Sarah Schulman explains that "[a]t many levels of human interaction there is the opportunity to conflate discomfort with threat, to make mistake internal anxiety for exterior danger, and in turn to escalate rather than resolve". ${ }^{203}$ At the same time, Schulman adopts a feminist approach that "the private sphere of power is organic to the meaning or the large frame of power". ${ }^{204}$ The private aspect of the classroom does not remove it from the larger institution to which it belongs, or the society that waits beyond the institution's walls. All of these relationships intersect with what happens in a classroom environment.

It is possible that even where a relational approach is adopted, those who experience traditional markings of privilege will feel threatened when they do not understand the perspective of the marginalized. This is particularly true when the

\footnotetext{
${ }^{203}$ Sarah Schulman, Conflict is Not Abuse: Overstating Harm, Community Responsibility, and the Duty of Repair (Vancouver, BC: Arsenal Pulp Press, 2016) at 17.

${ }^{204}$ Supra at 18.
} 
category of "privilege" is yielded as a weapon. ${ }^{205}$ The concept of privilege is difficult to manage. As I have mentioned, I benefit from certain markings of privilege and I feel the need to acknowledge them. While I am a woman, I do not experience oppression or marginalization in the traditional sense; but because I am a woman I am at risk for gender-based violence. To say that is not to deny the privilege that I experience as a white woman, but it is to recognize the relationship between myself and the social context in which I live. When students bring themselves to the classroom, they must be aware of how they respond to those who are different from them. It is not uncommon for what Narayan suggests will happen to actually manifest. Discomfort and hostility can arise when students feel that they are being misunderstood or attacked. Schulman argues that this can result in the justification of cruelty or shunning. ${ }^{206}$ It is understandable that students whose perspectives have been traditionally ignored would feel compelled to speak up, and a relational approach encourages the acknowledgement of these voices.

Paulo Freire is explicit in his explanation of social transformation through liberatory pedagogy as not replacing one form of domination for another ${ }^{207}$ The goal is not for the oppressed to burn it all down and oppress those who have oppressed them. To do so would return everybody to a state of dehumanization that can only be overcome through further conscientization. The acknowledgement of oppression should not be mistaken for the removal of privilege from those who traditionally possess it. He says:

${ }^{205}$ Pheobe Maltz Bovy, The Perils of Privilege: Why Injustice Can't Be Solved by Accusing Others of Advantage (New York: St. Martin's Press, 2017).

${ }^{206}$ Schulman, supra note 24 at 20.

${ }^{207}$ Freire, supra note 1. 
"the restraints used to ensure that the oppressors do not regain their former position is not the same thing as oppression". ${ }^{208}$ For students to acknowledge and listen to the experiences of those who are marginalized does not mean that the students doing the listening do not have valid points to contribute. However, to dismiss the situated experiences of the oppressed, because it does not line up with your understanding of the world, would fall into antidialogical action that is antithetical to a liberatory pedagogy.

\section{Concluding Remarks}

The pedagogical theories presented by Paulo Freire, bell hooks, and others are aimed at transforming education to transform society. Freire presents a method by which the oppressed become aware of their oppression and dehumanization. Through this process, they challenge the truth of the world that has been presented to them. Once conscientizacao is achieved, they restore humanity to themselves and to the oppressor, whose humanity was lost during the process of dehumanizing another. The stages of the pedagogy of the oppressed guarantee that through dialogical action liberation will be maintained. ${ }^{209}$ bell hooks expands on this process through her use of consciousnessraising and feminist theory. ${ }^{210}$ hooks argues for a pedagogical practice that recognizes students as full, embodied beings with complex lives and experiences. She is adamant about adopting an intersectional approach that creates space for critical analysis of these experiences.

\footnotetext{
208 Ibid at 57.

${ }^{209}$ Ibid.

${ }^{210}$ hooks supra note 21; supra note 43.
} 
These ideas are taken up by Jennifer J. Llewellyn and Kristina R. Llewellyn in their discussion of relational theory. Relational pedagogy does not just look at our relationship to one another but the relationship between education and society. The goal of education is not simply to teach or to learn, but to uncover what (and who) it is all for. ${ }^{211}$ In a relational pedagogy, students acknowledge their place in the world. This means acknowledging that you may never experience the same pain as another person in the room. That the social and political context that you exist in is the same but has vastly different consequences for you than for someone else. This does not mean that students with traditional privilege do not have important contributions to make, nor does it mean that those with the "privilege" of situated knowledge of oppression are precluded from having to do critical analysis. It means that situated knowledge offers a contextual standpoint from which to move forward.

${ }^{211}$ Llewellyn \& Llewellyn, supra note 54. 


\section{Chapter 4: Findings}

$\underline{\text { Introduction }}$

As I have mentioned throughout this thesis, the idea of educating judges on sexual assault law is not enough. We know how judges come to be, which means we should be intervening in their education much sooner than when they are already on the bench. Law school should not just serve as a mechanism to create lawyers by teaching the practice of the law, but as a place where students are meant to think critically about what they are learning.

The purpose of this chapter and its corresponding sections is not to criticize the professors and educators involved in these institutions. Where I mention explicit course names and discuss the content of their syllabi, I am in no way criticizing what professors have chosen to or not to include. The goals of this chapter are to show the current course offerings at Canadian law schools regarding gender-based violence and feminist legal issues, and to demonstrate that progressive and critical pedagogies can be used in law schools to better contextualize oppression and gender-based violence.

\section{Methodology Continued}

This thesis relies on both personal narrative as well as social semiotics. Halliday's combination of linguistics and social sciences, or social semiotics, accounts for the relationship between language and social structure. ${ }^{212}$ Language serves both 'ideational' and 'interpersonal' functions. The ideational function refers to the way that language

\footnotetext{
${ }^{212}$ Michael Alexander Kirkwood Halliday, "Language as a Social Semiotic" in Janet Maybin ed, Language and Literacy in Social Practice (Clevedon: Open University, 1993).
} 
"represents ideas about the world". Interpersonal refers to "facilitating interpersonal and social interactions". ${ }^{213}$ The use of personal narrative is combined with social semiotics with regards to the decision to explore data in a particular way. I do not presume to know what every student in a law school is thinking or feeling. I am exercising my understanding of the words and phrases in each course title and description, as a person who has studied law at both an undergraduate and graduate level. I am also drawing from my professional experience in the field of gender-based violence and advocacy. These positions form the basis for the use of social semiotics in my analysis of whether the course is coded as explicitly pertaining to the subject of gender-based violence and others as connected to broader feminist issues. My analysis found that many of the courses could have fallen into the general category of social equality issues and therefore could be considered connected. These included courses such as: evidence law, law and social welfare, law and resistance, etc. However, the content of these courses would have been beyond the scope of issues of gender-based violence. It would be impossible to cover every potential avenue for a discussion on issues of gender and sex in this thesis.

Additionally, I applied the social semiotics method to the criteria used to analyze the course syllabi. All the syllabi that I received were accessed electronically via email with the courses' professors. Since syllabi would provide me with more substantive answers than my initial analysis from a social semiotic standpoint, I generated a list of criteria to look for within these course syllabi. These included: feminist theory,

${ }^{213}$ Supra. 
intersectionality, $L G B T Q+$ perspectives, gender-based violence, and critical analysis. I endeavoured to look for a more exhaustive picture of the issues relating to gender-based violence since the syllabi offered a greater wealth of information than brief course descriptions or titles. In one case I found that my original categorization of a course did not line up with the substance of the course. Lastly, the inclusion of pedagogy as a criterion is due to the theoretical focus of this thesis.

A limitation of this method is that it can miss classes such as Professor Gillian Calder's Family Law class with its use of the theatre of violence. Calder's course will serve as a case study regarding critical pedagogy in legal education later in this chapter. On the one hand, the fact that Professor Calder's Family Law class engages with issues of domestic violence is a pleasant surprise. It will teach a broader range of students about the realities of gender-based violence and its intersections with family law. On the other hand, the fact that her Family Law class is not explicitly titled as incorporating genderbased violence means that it may be missed by some students who would be interested in this subject-matter.

All of the listed professors for the following courses were emailed regarding their syllabi. I was able to receive syllabi and reading lists for 5 of these 21 courses. In addition, Professor Gillian Calder-Associate Dean of Law at the University of Victoria - was forthcoming with information about my inquiry as well as information about her Family Law course. While I had not intended this project to dive into a case study, Professor Calder's generosity provided me with a look at existing sites of critical 
pedagogy. I had not intended to find a concrete example of the resistance to traditional pedagogy that I had hypothesized in this project. My intention was to discover if there was an interest in feminist, gender-based violence subject-matter in law schools. I had hoped that examining and analysing the course options would generate the answers I was looking for, and I was lucky enough to find a more in-depth example as well.

The use of one case to create a generalization is often criticized. It has limits and cannot paint a picture of every law school in Canada or the ways in which resistance and critical pedagogies are being used in other subjects. That being said, the use of a singlecase can still provide a powerful example. ${ }^{214}$ As noted by Bent Flyvbjerg, generalizations can often be reached by the use of a single case study. The implication that generalizations should be reached is "overvalued as source of scientific development". ${ }^{215}$

The law schools chosen as part of my data set are limited to those that teach English and are based on Common Law. For that reason, schools in Quebec have been excluded; while the University of Ottawa has been admitted due to the fact that while it has a French and Civil Law option, it does teach in English and have a Common-Law Section. The data collected is limited to the 2017-2018 academic year with one exception: the materials provided by Professor Calder for her Family Violence course are from the 2016 year. However, this course is not included in the dataset but serves as its own case study. Only the University of British Columbia, the University of New

\footnotetext{
${ }^{214}$ Bent Flyvbjerg, "Five Misunderstandings About Case-Study Research" (2006) Qualitative Inquiry 219. ${ }^{215}$ Supra at 228.
} 
Brunswick, and Dalhousie had general information about past courses-i.e. the year a course was taught, or a past syllabus. All of this information was accessed electronically.

To gather a picture of what the current offerings in Canadian law schools are, I began by compiling a list of Juris Doctor (JD) programs in Common Law, at schools which teach primarily in English. There are fifteen schools whose JD programs fit these criteria: The University of Alberta, The University of Calgary, The University of British Columbia (UBC), Dalhousie University, Lakehead University, The University of Manitoba, The University of New Brunswick (UNB), Osgoode Hall at York University (Osgoode), The University of Ottawa (uOttawa), Queen's University, The University of Saskatchewan, Thompson Rivers University (TRU), The University of Toronto, The University of Victoria (UVic), and the University of Western Ontario.

Of these 15 programs, 11 offer courses related to the subject of gender-based violence: UBC, The University of Calgary, The University of Manitoba, UNB, The University of Ottawa, Osgoode, Queen's University, The University of Saskatchewan, The University of Toronto, UVic, and the University of Western Ontario. 1 of these 11 courses is taught at both Toronto and York by the same professor, and is coded as the same course - meaning students from the University of Toronto are only able to take this course at York University.

Criminal Law is a required course in the first year for all law schools included in my study, and it is an area where there is potential for a discussion on gender-based violence. As mentioned in my literature review, to rely on criminal law as the vehicle to 
solve gender-based violence is naïve and limiting. While it is an issue of criminal law, it is not an issue that can be solved solely on the basis of criminal law. The pedagogical focus of this thesis seeks for ways of teaching and instructing on the subject of genderbased violence from within its broader social, political, and legal context.

The Landscape of Canadian Law Schools: Course Offerings in JD Programs

In the following table, courses are listed with " 1 " to indicate that it is offered once in the 2017-2018 academic year, "2" if it is offered more than once or in more than one section, and "0" for places where there are no courses regarding this subject matter.

\begin{tabular}{|c|c|c|}
\hline Institution & $\begin{array}{l}\text { Course(s) Offered - } \\
\text { Explicit }\end{array}$ & $\begin{array}{l}\text { Course(s) Offered - } \\
\text { Connected }\end{array}$ \\
\hline University of Alberta & $\begin{array}{l}\text { 1. Women, Law, and Social } \\
\text { Change }\end{array}$ & $\begin{array}{l}\text { 1. Law, Socio-Culture } \\
\text { Politics, and Women's } \\
\text { Health: Global Perspectives }\end{array}$ \\
\hline $\begin{array}{l}\text { University of British } \\
\text { Columbia (Peter A. Allard } \\
\text { School of Law) }\end{array}$ & $\begin{array}{l}\text { 1. Women, Law, and Social } \\
\text { Change } \\
\text { 1. The Law of Sexual } \\
\text { Offences }\end{array}$ & $\begin{array}{l}\text { 1. Reproduction \& The Law } \\
\text { 1. Sexuality \& The Law }\end{array}$ \\
\hline University of Calgary & 1. Feminist Legal Theory & 0 \\
\hline $\begin{array}{l}\text { Dalhousie University } \\
\text { (Schulich School of Law) }\end{array}$ & $\begin{array}{l}\text { 1. Gender, Sexualities, and } \\
\text { Law }\end{array}$ & 0 \\
\hline $\begin{array}{l}\text { Lakehead University (Bora } \\
\text { Laskin Faculty of Law) }\end{array}$ & 0 & 0 \\
\hline $\begin{array}{l}\text { University of Manitoba } \\
\text { (Robson Hall) }\end{array}$ & 0 & $\begin{array}{l}\text { 1. Sexual Expression, } \\
\text { Conduct, and Work in } \\
\text { Canada }\end{array}$ \\
\hline $\begin{array}{l}\text { University of New } \\
\text { Brunswick }\end{array}$ & $\begin{array}{l}\text { 1. Gender, Sexuality, and } \\
\text { Law }\end{array}$ & 1. Law \& Social Justice \\
\hline
\end{tabular}




\begin{tabular}{|l|l|l|}
\hline & 1. Gender and the Law & \\
\hline University of Ottawa & $\begin{array}{l}\text { 1. Feminist Legal Issues } \\
\text { 1. Sexuality, Gender, and } \\
\text { the Law }\end{array}$ & 0 \\
\hline Queen's University & $\begin{array}{l}\text { 2. Feminist Legal Studies } \\
\text { Workshop }\end{array}$ & 0 \\
\hline University of Saskatchewan & 0 & 0 \\
\hline University of Toronto & $\begin{array}{l}\text { 1. Law, Gender, and } \\
\text { Equality (this course is } \\
\text { taught at York University, } \\
\text { but offered to both } \\
\text { University of Toronto and } \\
\text { York University students) }\end{array}$ & \\
\hline $\begin{array}{l}\text { University of Victoria } \\
\text { (UVic) }\end{array}$ & 0 & $\begin{array}{l}\text { 1. Sexual Orientation and } \\
\text { the Law } \\
\text { 1. Law, Legal Practices, and } \\
\text { Social Change }\end{array}$ \\
\hline $\begin{array}{l}\text { University of Western } \\
\text { Ontario }\end{array}$ & $\begin{array}{l}\text { 1. Gendered Violence and } \\
\text { The Law }\end{array}$ & $\begin{array}{l}\text { 1. Sex Discrimination and } \\
\text { The Law }\end{array}$ \\
\hline $\begin{array}{l}\text { York University (Osgoode } \\
\text { Hall) }\end{array}$ & $\begin{array}{l}\text { 1. Law, Gender, and } \\
\text { Equality }\end{array}$ & \\
\hline
\end{tabular}

Table 1: Feminist and Gender-Based Violence Course Offerings in JD Programs

This data is illuminating for several reasons. First, none of these courses are required for the completion of a JD. Required courses in law schools are almost identical across the board and focus on doctrinal law. ${ }^{216}$ Is there room for a required course on gender-based violence? It is clear that there is an interest in this subject, but the answer to that question in particular is beyond the scope of this project. Second, in most cases there is only one class offered that is explicitly regarding, or connected to, the issue of gender-based violence and feminist legal issues.

\footnotetext{
216 The courses for the first year of most Canadian law schools are criminal law, property, torts, contracts, or some combination thereof.
} 
In my analysis of the course syllabi that were made available to me, I focused on the listed objectives in the course description and the listed readings. Once again, I relied on my position as both a student and an educator to analyze which terms to look for within these courses. The reason that I separated intersectionality and $L G B T Q^{+}$ perspectives is based on my experience in discussions on gender-based violence. Intersectionality is taken to include race, but does not always include the perspectives of queer, non-binary, and transgender folks. As the aforementioned pages state, the inclusion of pedagogy is a result of the aims of this project, and the focus on critical pedagogy as a vehicle for the discussion of gender-based violence.

The syllabi that were made available to me were from courses coded as explicit as well as connected. In the case of Sexual Orientation and The Law, my initial categorization as connected proved to be wrong.

\begin{tabular}{|l|l|l|l|l|l|l|}
\hline Course & Criteria & \multicolumn{5}{|l|}{} \\
\hline & $\begin{array}{l}\text { Feminist } \\
\text { Theory }\end{array}$ & Intersectionality & $\begin{array}{l}\text { LGBTQ+ } \\
\text { Perspectives }\end{array}$ & $\begin{array}{l}\text { Gender- } \\
\text { Based } \\
\text { Violence }\end{array}$ & $\begin{array}{l}\text { Critical } \\
\text { Analysis }\end{array}$ & Pedagogy \\
\hline $\begin{array}{l}\text { Women, } \\
\text { Law, and } \\
\text { Social } \\
\text { Change }\end{array}$ & $\mathrm{X}$ & $\mathrm{X}$ & $\mathrm{X}$ & $\mathrm{X}$ & $\mathrm{X}$ & \\
\hline $\begin{array}{l}\text { Reproduction } \\
\text { \& The Law }\end{array}$ & $\mathrm{X}$ & & $\mathrm{X}$ & & & \\
\hline $\begin{array}{l}\text { Sexuality, } \\
\text { Gender, and } \\
\text { Law }\end{array}$ & $\mathrm{X}$ & $\mathrm{X}$ & $\mathrm{X}$ & & & \\
\hline $\begin{array}{l}\text { Feminist } \\
\text { Legal Issues }\end{array}$ & $\mathrm{X}$ & $\mathrm{X}$ & & & & \\
\hline
\end{tabular}




\begin{tabular}{|l|l|l|l|l|l|l|}
\hline $\begin{array}{l}\text { Sexual } \\
\text { Orientation } \\
\text { and the Law }\end{array}$ & $\mathrm{X}$ & $\mathrm{X}$ & $\mathrm{X}$ & & $\mathrm{X}$ & $\mathrm{X}$ \\
\hline
\end{tabular}

Table 2: Themes of Course Syllabi

First and foremost, this data shows that there is space for this subject-matter in Canadian law schools. There is room to talk about these issues before students have long-since graduated, are practicing law, and are headed towards a career as a judge. There is space to teach an uncomfortable subject in a contextual and dynamic way. An example of this practice can be seen in the form of the critical pedagogy used by Professor Gillian Calder, the Associate Dean of Law at the University in Victoria. In both her Sexual Orientation and The Law course, as well as her course on Family Law, Professor Calder uses theatre and play-reading as a way to bring law and legal practice into the context of human experience. In the following section I will provide a case study of her use of critical and embodied pedagogy.

Case Study: Theatre and Embodied Pedagogy at The University of Victoria Reflections from Professor Gillian Calder, Associate Dean of Law

This case study focuses on the use of theatre as method of teaching legal education. Professor Calder provided me with her reading list and the script for her theatre of oppression seminar used during her Family Law course. Additionally, she provided me with information on the use of theatre in her Sexual Orientation and the Law course. Both Calder and one of her past students have written on their experiences in this course. These pieces will be used in this case study as well. In both instances theatre is 
used as a way for students to place their knowledge in context. They embody what they have learned to put theory into action. ${ }^{217}$

As part of her Sexual Orientation and The Law course, Professor Calder has had her students perform a reading of " 8 ", a play by Dustin Lance Black. The students are required to use the case Perry v. Schwarzenegger to create the courtroom drama. The plaintiffs in this case argued against California's Proposition 8, which would only recognize marriages of men and women, as legitimate. The use of this case allows students to see actual cases in the greater context of sexuality, discrimination, and the law. ${ }^{218}$ In her own reflection on the production of " 8 ", Calder explains her intentions behind the design of the course. Theatre is used to "engage students on critical questions about the relationship between law and sexuality looking both at how sexuality and law are constructed in the world around us, and at how law and its tools shaped and place limits of queer movements", ${ }^{219}$ While Calder ensures that the students have access to proper support - including theatre professionals - the primary responsibility for performing the play is placed upon the students themselves.

It is paramount to note that play-reading is used in conjunction with course readings. In Sexual Orientation and The Law, the students read works by prominent feminist theorists such as Judith Butler, Janet Halley, Dean Spade, and more. To prepare

\footnotetext{
${ }^{217}$ Gillian Calder, Book Review of Not The Marrying Kind: A Feminist Critique of Same-Sex Marriage by Nicola Barker (2013) Canadian Journal of Family Law 114, [Calder, 2013]; "Guantanamo: Using PlayReading to Teach Law" (2010) Canadian Theatre Review 44, [Calder, 2010].

218 Supra

219 Ibid at 115.
} 
for the play, other exercises throughout the semester included "mapping; mural making; image theatre; queer dressing; and storytelling as well as rehearing and staging the play". ${ }^{220}$ Calder's use of these pedagogical methods ensures that the students are prepared not only to understand the course content from their position as legal academics, but as students with complex lives and experiences of their own.

In her review of Nicola Barker's Not the Marrying Kind: A Feminist Critique of Same-Sex Marriage, Calder works through the anxiety and unease that she felt at the end of the production of "8". Calder's experiences demonstrate how using critical pedagogy in legal education is not easy, and she is open and honest about her concerns and worries. Barker's book centres around the question of whether the institution of marriage can be changed; whether it can evolve into something that is removed from its roots in patriarchy. ${ }^{221}$ Calder's main critique of Barker's book centers around questions of family. Although Barker used feminist and queer theory to analyze the question of marriage as a hostile institution, Calder is critical of the lack of attention paid to other people that fall outside the traditional family and marriage model, including queer, non-binary, and single-parent families. ${ }^{222}$ Through her own criticism of Baker, Calder is able to reflect on the criticism she had toward the production of "8".

\footnotetext{
${ }^{220}$ Ibid page 116.

${ }^{221}$ Nicola Barker, Not the Marrying Kind: A Feminist Critique of Same-Sex Marriage (UK: Palgrave Macmillan, 2012).

${ }^{222}$ Calder, supra note 6.
} 
The production of " 8 " requires students "to embody the American pursuit of formal equality". ${ }^{223}$ This focus on the formal legal equality of marriage overlooks the deeper substantive issues that affect the people's relationships—like race, gender, and class - and potentially provides a unidimensional and inadequate portrayal of the varied experiences different people have with marriage equality. At the same time, the students' honest portrayals created the appropriate space for critiques of these formal legal arguments to emerge. ${ }^{224}$ This contributed to the positive experiences and deeper understandings of the students. Additionally, Calder responds to the criticism that the play only gives one side of the argument. She argues that despite the fact that "8" was written from trial transcripts - meaning the dialogue reflects words that were actually spoken - the interpretation by an award-winning playwright allows the content to remain entertaining and politically engaging. ${ }^{225}$

Calder maintains that the format of the play, in combination with the course materials and exercises, allowed the students to "truly understand the use of law for social change from a theoretical perspective". ${ }^{226}$ The play itself focuses on the idea that marriage is something that all people should attain, and that the law is the best mechanism to achieve social justice goals. ${ }^{227}$ However, this is not the reality for everybody. Calder's own experience with Barker's texts reflects that. What Calder did

\footnotetext{
${ }^{223}$ Ibid.

${ }^{224}$ Ibid.

${ }^{225}$ Ibid.

${ }^{226}$ Ibid at 129.

${ }^{227}$ Ibid.
} 
was ensure that the students were able to see the issue of marriage as more than just a single-issue problem of formal equality - they could see the diverse and intersecting problems that extend beyond marriage, such as "faith, racism, classism, transphobia, mental health and care-giving". 228

Similarly, Calder acknowledges that the characters in the play are not diverse but that the students found a way to confront this through the queer theory lens provided by their course materials. She explains that in their casting for the play, the students were not concerned with the race or gender of the character that they chose. This lens used by the students brings Calder's reflection full-circle. She argues that the method and pedagogy behind the play allow both herself and her students to realize that the idea of the legal family needs to be understood from a queer perspective. She states, "[ $\mathrm{t}]$ he more we can que(e)ry why law centres some forms of families over others, and support those who find themselves painfully excluded, the better all of our lived experiences will be". ${ }^{229}$

In “Perry v. Schwarzenegger: An Opportunity to 'Do' Law Differently”, Jasreet Badyal reflects on her experience in Professor Calder's Sexual Orientation and the Law course. Badyal is interested not only in the experience of embodied pedagogy, but what the purpose of legal education is. She remarks that in her experience as a law student, most people still view the purpose of legal education as if the ability to master legal

\footnotetext{
228 Ibid at 130 .

${ }^{229} \mathrm{Ibid}$ at 132.
} 
doctrine is what is necessary for being a good legal advocate. ${ }^{230}$ The pedagogy and practices enacted by Professor Calder allowed Badyal and her colleagues to step outside the understanding of law and the legal profession that their traditional classroom experiences had given them. On an emotional level, the use of communication-both in the production of "8" and in their seminar discussions - brought empathy into their legal education. ${ }^{231}$ Students had to rely and depend on one another in a way that was collaborative and cooperative, thereby working against the tendency toward competitiveness that is commonly experienced in traditional law classrooms.

The pedagogical disruptions to traditional law classrooms practiced by Professor Calder did not just occur as part of classroom discussion, but through the use of the educational space itself. Both Calder and Badyal mention the use of the largest lecture hall on campus for the production of " 8 " as integral to their experience. A space that is usually reserved for traditional academic lectures was disrupted through the use of a different ritual. ${ }^{232}$ Badyal notes that the process of ritual contributes to social and power relations, and that the disruption of the traditional lecture space is significant in the disruption of existing hierarchies. In this case, Badyal's experiences in Calder's course disrupted the traditional way that students are taught the law through a hierarchal model that focuses on the mastery of legal doctrine by students who are filled with knowledge by an established lawyer or legal expert.

\footnotetext{
${ }^{230}$ Jasreet Badyal, "Perry v. Schwarzenegger: An Opportunity to 'Do' Law Differently” (2014) 19 Appeal. Review of Current Law and Law Reform 3.

${ }^{231}$ Supra.

${ }^{232}$ Supra.
} 
Family Law and the Theatre of the Oppressed

It is perhaps less surprising to find a critical pedagogy in a course titled Sexual

Orientation and the Law than it is in Family Law. Given the experiences of

discrimination and oppression associated with sexual orientation—legally, socially, politically, culturally — it would follow that to teach the subject in a meaningful way, a pedagogy that engages with oppression should be used. Badyal referred to this "otherness" as what helped to foster such a dynamic and respectful classroom. Most of the students enrolled in Sexual Orientation and the Law belonged to a marginalized group and had chosen the course as a result of that experience. ${ }^{233}$ The inclusion of a pedagogy that engages with oppression in a course on family law is less obvious. This was a limitation of my research method. Calder's example demonstrates that it is possible for critical pedagogies to be used in more doctrinal or traditional law courses. Calder's use of theatre serves as an example of critical pedagogy in legal education, both in courses geared towards "the other", as in Sexual Orientation and the Law, and courses that pertain to more traditional legal subjects, such as Family Law.

In her lecture on family violence, Professor Calder has her students use both Augusto Boal's Theatre of the Oppressed and a scene titled "Forum Theatre on Domestic Violence" from the play Canadian Tango. ${ }^{234}$ The instructions for Forum Theatre in this lecture includes the use of personal experience as well as course material, and focuses on

${ }^{233}$ Ibid.

${ }^{234}$ Augusto Boal, Theatre of the Oppressed (New York: Theatre Communications Group, 1985); Augusto Boal, Games for Actors and Non-Actors, Second Edition (London: Routledge, 2002; Lina de Guevara "Canadian Tango" (Victoria: Puente Theatre, 1991). 
learning instead of winning a case. When a scene is acted out students can stop the scene to talk, and encourage discussion and participation. These interventions are also part of the "role-play" and can include phone calls to the family in the scene, kids speaking up, the woman leaving, neighbours arriving, police arriving, bystander intervention, and more. ${ }^{235}$ After each intervention, students must discuss what they learned about domestic violence and power imbalances. Once the scene is over, students must discuss what they have learned, other ways that the community can help, why the woman would stay in an abusive situation, and what they learned from trying to change the circumstances with their interventions. ${ }^{236}$

By virtue of being a law class, there is discussion through the instructions and course materials for this seminar about the legal remedies available through family law and criminal law (among others). Students are intended to understand how the law handles cases of intimate partner violence, while learning the intricacies of this type of violence. Additionally, Calder draws attention to the fact that while the Forum revolves around the abuse of women by men, abuse occurs in gay and lesbian relationships, and is experienced by trans, genderqueer, and non-binary individuals as well. ${ }^{237}$ Similar to the play used in Sexual Orientation and the Law, Calder has found a way to provide students with context for these grey areas that law does not account for.

\footnotetext{
${ }^{235}$ Gillian Calder, Violence in Relationships, Lecture Outline (Faculty of Law, University of Victoria, Fall 2016); Intimate Violence, Lecture outline, Fall 2016).

${ }^{236}$ Calder, supra; Gillian Calder, Sexual Orientation and The Law, Course Syllabus (Faculty of Law, University of Victoria, Fall 2017); Gillian Calder, Sexual Orientation and The Law, Reading Outline (Faculty of Law, University of Victoria, Fall 2017).

${ }^{237}$ Calder, supra.
} 
Queries and Concerns: Role-Play, Embodied Trauma, and Relationality

While I have some questions and concerns about the practical implications of using theatre to teach law, I find that each one is remedied - if not wholly, then in partby the evidence of Calder's work, syllabus, and the experiences described by her student. Additionally, I reflect on my experience using role-play to teach sexual assault resistance. My first concern surrounds the embodiment of trauma through role-playing and play reading.

In the program that I facilitate, participants are required to do numerous roleplaying activities. Some of these activities require the participants to take on the role of a coercive male. It results in both uncomfortable laughter and usually one person will leave the room. To embody the role of a person who is coercive is a difficult task. When you consider the likelihood that one of the women in the room has been assaulted, this roleplay is particularly jarring. My understanding of trauma as a whole-body experience is partly informed by my training as a peer support worker at CUSASC. We learn both the psychological and physiological effects of trauma so that we can best support the people that we see. Trauma is not a single moment or symptom. It is not a linear experience but a complex and individualized experience with deep psychological, physiological, and emotional effects.

Susan Brison uses her own experience of rape to highlight the lasting impact of trauma. In “Outliving Oneself: Trauma, Memory and Personal Identity”, Brison explains that trauma removes a person from their sense of self. It severs the connection to the body 
and deeply impacts the experience of how to be oneself. ${ }^{238}$ Dale Spencer engages with a similar conceptualization of trauma in his work on the event of victimization. ${ }^{239}$ Spencer challenges the tendency for victimology to bypass the event that creates victimization and instead focuses on the category of 'victim'. ${ }^{240}$ The focus on the label of 'victim' does not account for "the embodied experience of trauma that potentially disrupts and/or results in a loss of self-hood and a traumatized body's way of being-in-the-world". ${ }^{241}$

The understanding of embodiment put forward by both Brison and Spencer, albeit in different ways, informs my first concern with Calder's embodied pedagogy. If trauma severs a person from their body, from their understanding of self, how can another person really embody that experience? This is not to assume that Calder is claiming that students will have a flawless insight into the experience of trauma. Professor Calder's use of queer theory in her course syllabus is useful here. Judith Butler explains the body as "that which can occupy the norm in myriad ways, exceed the norm, rework the norm, and expose realities to which we thought were confined as open to transformation". ${ }^{242}$ The use of the body in pedagogy allows the students to experience realities that are absent from the norms presented by legal texts and doctrine.

\footnotetext{
${ }^{238}$ Susan Brison, "Outliving Oneself: Trauma, Memory and Personal Identity" in Diana T. Meyers ed, Feminist Rethink the Self (Boulder: Westview Press, 1996).

${ }^{239}$ Dale Spencer, "Event and Victimization" (2011) Criminal Law and Philosophy 39.

${ }^{240}$ Ibid at 46.

${ }^{241}$ Ibid.

242 Judith Butler, Undoing Gender (New York: Routledge, 2004) at 217.
} 
In her reflection, Badyal comments that she became "more intimately aware of the sensations and emotions that a different character must be feeling". ${ }^{243}$ The use of theatre was integral to the understanding of empathy as a skill that is essential to the practice of law. ${ }^{244}$ Moreover, if students are encouraged to engage with an antioppression lens, they should be able to see the limitations of their understanding. While empathy should be integral to the practice of law, learning, and of life, we can never really feel what another person has felt. Particularly if that feeling is the result of trauma.

This brings me to my second and third concerns: emotions and situated knowledges. I am concerned about those people who have experienced trauma and the effect of watching their classmates turn their experience into "performance". Those who have experienced trauma may have the privilege of situated knowledge. ${ }^{245}$ This can contribute to a hostility toward — and within—open dialogue as this insider knowledge grants the 'other' a greater understanding of the experience being discussed. ${ }^{246}$ For example, if we consider this within the context of Calder's course, it is possible for those in the position of 'other' - those who are marginalized and oppressed - to feel uncomfortable when watching students who do not share this experience, inhabit the role. For the person inhabiting the role of the 'other', they can leave these experiences behind.

\footnotetext{
243 Supra at 15.

244 Ibid note 22.

${ }^{245}$ Uma Narayan "Working Together Across Difference: Some Considerations on Emotions and Political Practice" (1988) Hypatia 31; Donna Harraway, "Situated Knowledges: The Science in Question in Feminism and the Privilege of Partial Perspectives" in Sandra Harding ed, The Feminist Standpoint Theory Reader: Intellectual \& Political Controversies (New York: Routledge, 2004).

246 Supra.
} 
But for the student who experiences marginalization as part of their daily experience, this is not the case. They must carry their experiences and marginalization with them at all times. It is possible for this practice of role-playing to elicit tense emotions in the 'other'.

Where do these emotions go? If a student has experience with a situation similar to that acted out in the seminar on family violence, how are they to continue to engage with the material and contribute to a dialogical classroom? Calder and Cowan answer this question in their own acknowledgment of the discomforts that come with using theatre as pedagogy. While there is a concern that theatre will make light of the educational process, it still provides an avenue for students to engage with the material in an empathetic and nuanced way. ${ }^{247}$ In particular, it "offers students of law a powerful means through which to engage with what is often impossible to articulate". ${ }^{248}$ The use of theatre gestures towards students grasping a cursory understanding of just how complex the experiences and situated knowledges of others are in their context.

Nicolas Bourriaud's Relational Aesthetics provides a useful explanation of this learning experience. He explains relational art as creating spaces "whose rhythm contrasts with those structuring everyday life" thereby disrupting the traditional social communication with art as passive. ${ }^{249}$ Calder has used theatre to create a space where the everyday life of law schools is disrupted with an interactive form of communication and

${ }^{247}$ Gillian Calder \& Sharon Cowan, "Re-Imaging Equality: Meaning and Movement" (2008) 29 A Fem LJ 109 [Calder \& Cowan]; Gillian Calder, "Guantanamo: Using a Play-reading to Teach Law" (2010) 142 Canadian Theatre Review 44 [Calder 2010]. ${ }^{248}$ Supra at 48.

${ }^{249}$ Nicolas Bourriard, Relational Aesthetics (France: Les Presse Du Reel, 1998) at 16. 
practice. Similarly, Kristin Hunt explains that "much like relational art, relational pedagogy constructs instructional design as an invitation into intersubjective exchange rather than, or in addition to, a system for disseminating knowledge". ${ }^{250}$ Calder's critical and dynamic pedagogical approaches can account for the ways that different people experience the world and possess knowledge. Hers is a concrete example of both critical pedagogy, and the communication that is integral to a relational approach. In the syllabus for Sexual Orientation and the Law, Professor Calder explicitly mentions her teaching methodology that for a positive learning experience, inclusivity and respect are paramount. ${ }^{251}$ This includes reflecting on, and challenging, what 'inclusivity' and 'respect' mean, as well as being mindful of the way that language is used both on an individual level and as part of the larger group. Students are responsible for the role they have and the power they possess in the classroom and for the creation of a dialogical space. This is not an easy process and it is unlikely to be perfect.

While Calder's unique and innovative approach to legal education has been a positive experience, there is also the possibility that students will be resistant to this type of education. ${ }^{252}$ In the course-work year of my Master's Degree, I took a course on emotional geographies. It was by far the most unique educational experience I have ever had. We were broken into small groups for our readings and we spent the last hour of

\footnotetext{
${ }^{250}$ Kristin Hunt "Kristin Hunt, "Classroom Cons and Assigning Activism: Ethical Issues in Relational Pedagogy" 25 Theatre Topics 199.

${ }^{251}$ Calder, ibid note 36.

252 Patti Lather, Getting Smart: Feminist Research and Pedagogy With/In the Postmodern (New York: Routledge, 1991).
} 
class working on art-journals as a way to understand and engage with our reading materials. ${ }^{253}$ For our final presentations, we were to reflect on our journals and the patterns that we saw, while tying it back to the major themes of the course. As a student whose education has primarily been in the Department of Law and Legal Studies, this experience felt very strange and almost surreal. I doubted my place in the room and what I could contribute. At the same time, that experience has informed this research and has fundamentally changed the way that I view education. That being said, my work in emotional geographies had many moments of discomfort, joy, and overwhelming emotion. It was not easy to be a part of and I am not assuming that changing the way we teach (and learn) will be without numerous challenges.

\section{Concluding Remarks}

The work of Gillian Calder shows that there is space for this type of education in Canadian law schools if we choose to make it; if we choose to disrupt the traditional spaces that are given to us. Such a disruption does not have to come in the form of theatre. It can be derived from the methods presented in the previous chapter, including liberatory and feminist pedagogy. What is important is an acknowledgement that this is not impossible. It is already being done at the University of Victoria and likely elsewhere.

This data sample is limited and further research should go into the varying experiences of students who have been taught through critical pedagogies. Professor Calder serves as one example of the way that legal education can engage with the

\footnotetext{
${ }^{253}$ Sophie Tamas, Emotional Geographies, Course Syllabus (Faculty of Canadian Studies, Carleton University, Winter 2017).
} 
complex relationships between law, politics, and oppression. Her use of embodied pedagogy provides hands-on experience with relational theory. Kristen LaMantia, Holly Wagner, and Lynn Bohecker's work on ally development through feminist pedagogy is particularly useful here. ${ }^{254}$ Although they are speaking within the context of counselling education and not legal education, I believe that is beneficial to adopt their understanding of intersectionality in the classroom. The authors argue that intersectionality cannot just be described in a traditional "lecture-based pedagogy" 255 , but must move into the lived experience of intersecting forms of oppression and inequality. They rely upon "experiential learning theory" (ELT), which comes from a "constructivist, holistic, and integrative stance, which assumes that ideas are not fixed, but derived from, and continually modified through, experience". ${ }^{256}$ The experience provided by Calder's use of theatre differs from that of the experiential education (EE) or community legal services (CLS) model due to its reliance on embodiment. Students see, hear, and experience stories of oppression—not just through textual engagement, but with their bodies. ${ }^{257}$ This can help subvert the perspective that those with situated knowledge are offered a particular form of privilege within the discussion of marginalization and trauma. Although students may come from backgrounds that fall under a more traditional form of privilege (white, cisgender, straight, middle-class), they are able to imbue an experience

\footnotetext{
${ }^{254}$ Kristen LaMantia, Holly Wagner, \& Lynn Bohecker, "Ally Development Through Feminist Pedagogy: A Systemic Focus on Intersectionality" (2015) Journal of LGBT Issues in Counselling 136.

${ }^{255}$ Supra at 140.

${ }^{256} \mathrm{Ibid}$ at 141.

${ }^{257}$ Badyal, supra note 19; Calder \& Cowan, supra note 36.
} 
that is different from their own. Similarly, students who have witnessed and experienced oppression can see the ways that those who have different privileges also have worthy contributions and knowledges.

Empathy and (certain) emotions are not always welcome in university classrooms - law school or otherwise. Emotions like anxiety, paranoia, or shame can be seen as ugly or irrational; whereas pride and confidence are part in parcel with the traditional pedagogical model. ${ }^{258}$ The use of embodied pedagogy challenges the notion that seemingly 'ugly feelings' are dichotomous to rational thought and educational environments. The same is true of critical and feminist pedagogies, such as those put forward by bell hooks and Paulo Freire, as well as Jennifer J. Llewellyn and Kristin R. Llewellyn. It is through our connection to one another, our acknowledgment of our humanity and challenging the dehumanization that is encouraged through forms of oppression, that we can learn more than traditional education allows.

${ }^{258}$ Sianne Ngai, Ugly Feelings (Cambridge, MA: Harvard University Press, 2007) at 7. 


\section{Chapter 5: Conclusion}

Dean Spade explains that people often seek law school as a way to become involved with social change and social justice movements. He reflects on conversations he has with students interested in law school, asking his advice on what they can do and whether it is the right choice for them. To respond to these concerns, he created a list of things to consider when deciding to go to law school. His points include: "most legal work maintains systems of maldistribution, it does not transform them; lots of legal work that needs to be done to help poor people can be done without a law degree; [...] and law school is a very conservative training and rarely a critical intellectual experience". ${ }^{259}$ The latter is particularly difficult to navigate for students who experience oppression and marginalization.

The experiences of oppressed or marginalized folks are not part of the traditional pedagogical practices of university. Students who face additional forms of marginalization are often dismissed or alienated in academia. The traditional conceptualizations of knowledge in university view knowledge as objective and demonstrated through empirical data, not experience. This has been challenged by feminist academics, including feminist epistemologists and standpoint theorists to incorporate the use of situated knowledge. The experience of those who are oppressed

\footnotetext{
${ }^{259}$ Dean Spade, "For Those Considering Law School" Blog post. Retrieved from: $<$ http://www.deanspade.net/wp-content/uploads/2010/10/For-Those-Considering-Law-School-Nov 2010.pdf $>$ at $1-8$.
} 
offers a standpoint by which to being a contextual critical analysis of systems of oppression-including the law. The process of incorporating progressive pedagogy into post-secondary institutions, particularly law schools, will not be easy. My hope is that the use of empirical, practical, and theoretical work can provide a basis for moving forward with greater work and research around this subject matter.

This thesis has used course offerings and case study to demonstrate the possibilities of anti-oppression and gender-based violence education in Canadian law schools. I have relied on the pedagogical theories of Paulo Freire, bell hooks, and others, to provide critiques and alternative options to traditional pedagogy. The case study regarding Professor Gillian Calder serves as a strong example of resisting traditional pedagogies. Her use of critical pedagogy in the form of theatre and play-reading offers a unique and hands-on experience with intersectional and relational approaches.

I am not suggesting that the process of adapting or changing traditional pedagogical practices will be easy. It would be naïve of me to expect all university classrooms to be feminist ones. The process of acknowledging and working through systems of oppression is difficult and often uncomfortable. For students who have markings of traditional privilege, acknowledging your position in structures of oppression can be uneasy. I have found this is the case even within feminist spaces. Even where issues of race, class, and gender can be intellectually understood they are often not placed into context. ${ }^{260}$ The approaches discussed in this thesis seek to move past an intellectual

\footnotetext{
260 bell hooks, Teaching to Transgress: Education as the Practice of Freedom (New York: Routledge,
} 
acknowledgement and move into a relational and intersectional one. It is one thing for students to read a piece of literature for the sake of diversity and it is another to actually move past the text and understand its social, political, and historical context.

The question of context relies on listening to the experiences of students and giving weight to situated knowledges. For example, when studying gender-based violence, it is perfectly reasonable and rational to respond emotionally. The reality and urgency of this violence is real and personal, and students who face additional layers of marginalization or victimization should not be expected to pretend that the issue does not affect them. To engage with course material as if it has no implications outside of the classroom contributes to feelings of exclusion and the marginalization of voices that are silenced. $^{261}$

This thesis has demonstrated that these feelings and contextual understandings can be used in educational settings. This does not mean that possessing situated knowledge precludes students from having to engage with critical analysis. What this looks like moving forward is treating students as whole, embodied beings with unique sets of experiences and knowledges. ${ }^{262}$ The introduction of situated knowledges will affect the

1994).

${ }^{261}$ hooks, supra note 3; Christine M. Koggel, "A Relational Approach to Equality" in Jocelyn Downie \& Jennifer J. Llewellyn eds, Being Relational: Reflections on Relational Theory and Health Law (Canada: UBC Press, 2012); Jill Stauffer, Ethical Loneliness: The Injustice of Not Being Heard (New York: Columbia University Press, 2015).

${ }^{262}$ Supra; Linda Briskin, Feminist Pedagogy: Teaching and Learning Liberation (Ottawa: CRIAW, 1992); Kristina R. Llewellyn \& Jennifer J. Llewellyn, "A Restorative Approach to Learning: Relational Theory as Feminist Pedagogy in Universities" in Tracy Penny Light, Jane Nicholas, and Renée Bondy eds, Feminist Pedagogy in Higher Education: Critical Theory and Practice (Canada: Wilfrid Laurier University Press, 2015). 
classroom in different ways, and emotional reactions should not be turned away as irrational or antithetical to the goals of education. ${ }^{263}$ I have found university to be a particularly emotional experience, but those emotions are not always appreciated in classroom settings. The introduction of negative emotions as valid responses does not mean that students are free to behave inappropriately. It means that with a relational approach we can see how the content that we study affects us and our lives.

${ }^{263}$ Supra; Carolyn Pedwell \& Anne Whitehead, “Affecting Feminism: Questions of Feeling in Feminist Theory" (2012) 13 Feminist Theory 115. 


\section{Bibliography}

\section{LEGISLATION}

Canadian Charter of Rights and Freedoms, Part I of the Constitution Act, 1982, being Schedule B to the Canada Act 1982 (UK), 1982, c.11

Criminal Code, R.S.C., 1985, c C-46, s. 271.

Bill C-46, An Act to amend the Criminal Code (production of records in sexual offence proceedings), 2d Sess.,35 ${ }^{\text {th }}$ Parl., S.C. 1997 c.30 (assented to 25 April 1997).

Bill C-337, An Act to amend the Judges Act and the Criminal Code (sexual assault) $1^{\text {st }}$ Sess., 42 ${ }^{\text {nd }}$ Parl., Canada, 2017, (first reading 23 February 2017).

\section{SECONDARY MATERIALS: ARTICLES}

Badyal, Jasreet. "Perry v. Schwarzenegger: An Opportunity to 'Do' Law Differently” (2014) 19 Appeal: Review of Current Law and Law Reform 3.

Brison, Susan. "Outliving Oneself: Trauma, Memory and Personal Identity" in Diana T. Meyers ed, Feminist Rethink the Self (Boulder: Westview Press, 1996).

Briskin, Linda. "Activist Feminist Pedagogy: Privileging Agency in Troubled Times" in Tracy Penny Light, Jane Nicholas, \& Renée Bondy eds, Feminist Pedagogy in Higher Education: Critical Theory and Practice (Canada: Wilfrid Laurier University Press, 2015).

Buchwald, Emilie. "Raising Girls For the $21^{\text {st }}$ Century" in Emilie Buchwald, Pamela R. Fletcher, and Martha Roth eds, Transforming a Rape Culture (Minneapolis, MN: Milkwood Editions, 1993). 
Burns, Leighmann., \& Suleman, Zara. "Justicia In Your Face: How to Survive Law as An Anti-Colonial, Anti-Racist, Feminist Activist" in Elizabeth Sheehy \& Sheila McIntrye eds, Calling For Change: Women, Law, and the Legal Profession (Canada: University of Ottawa Press, 2006).

Calder, Gillian. \& Cowan, Sharon. "Re-Imaging Equality: Meaning and Movement" (2008) 29 A. Fem LJ 109.

Calder, Gillian. "Guantanamo: Using Play-Reading to Teach Law” (2010) Canadian Theatre Review 44.

Gillian Calder, Book Review of Not The Marrying Kind: A Feminist Critique of SameSex Marriage by Nicola Barker (2013) Canadian Journal of Family Law 114 Carbado, Devon W., Crenshaw, Kimberlé Williams., Mays, Vickie M., \& Tomlinson, Barbara. "Intersectionality: Mapping the Movements of a Theory" (2013) Du Bois Review 10(2), 303.

Cabrera, Nolan. "Exposing Whiteness in Higher Education: White Male College Students Minimizing Racism, Claiming Victimization, and Recreating White Supremacy" (2014) (2014) 17 Race, Ethnicity, and Education 30.

Cho, Sumi., Crenshaw, Kimberlé Williams., \& McCall, Leslie. “Toward a Field of Intersectionality Studies: Theory, Applications, and Praxis" (2013) Signs 875.

Code, Lorraine. "Ignorance, Injustice and the Politics of Knowledge: Feminist Epistemology Now" (2014) 29 Australian Feminist Studies 148. 
Crenshaw, Kimberlé Williams. "Demarginalizing the Intersection of Race and Sex: A Black Feminist Critique of Antidiscrimination Doctrine, Feminist Theory and Antiracist Politics” (1989) University of Chicago Legal Forum 139.

Crenshaw, Kimberlé Williams. "Mapping the Margins: Intersectionality, Identity Politics, and Violence Against Women of Colour" (1991) Stanford Law Review 43(6) 1241.

Crenshaw, Kimberlé Williams. "From Private Violence to Mass Incarceration: Thinking Intersectionally About Women, Race, and Social Control” (2012) UCLA Law Review 14.

Ehrlich, Susan. "Perpetuating — and Resisting — Rape Myths in Trial Discourse" in Elizabeth Sheehy eds, Sexual Assault in Canada: Law, Legal Practice, and Women's Activism (Canada: University of Ottawa Press, 2012)

Fairbairn, Jordan. \& Spencer, Dale. "Virtualized Violence and Anonymous Juries: Unpacking Steubenville's 'Big Red' Sexual Assault Case and the Role of Social Media” (2017) Feminist Criminology 1.

Flyvbjerg, Bent. "Five Misunderstandings About Case-Study Research” (2006) Qualitative Inquiry 219.

Gondezi, A., Schwartz, M.D., \& W.S. Dekeseredy, W.S. “Toward A Gendered Social Bond/Male Peer Support Theory of University Woman Abuse” (2001) 10 Critical Criminology 1. 
Gotell, Lise. "The Idea Victim, the Hysterical Complainant, and the Disclosure of Confidential Records: The Implications of the Charter for Sexual Assault Law" (2002) 40 Osgoode Hall Law Journal 251.

Gotell, Lise. "The Discursive Disappearance of Sexualized Violence: Feminist Law Reform, Judicial Resistance, and Neo-Liberal Sexual Citizenship” in Dorothy E. Chunn, Susan Boyd, \& Hester Lessard eds, Reaction and Resistance: Feminism, Law, and Social Change (Canada: UBC Press, 2008).

Grant, Isabel. "Intimate Partner Criminal Harassment Through a Lens of Responsibilization” (2015) Osgoode Legal Studies Research Paper Series 87. Halliday, M.A.K., "Language as a Social Semiotic" in Janet Maybin ed, Language and Literacy in Social Practice (Clevedon: Open University, 1993).

Harding, Sandra. "Introduction: Standpoint Theory as a Site of Political, Philosophic, and Scientific Debate" in Sandra Harding ed, The Feminist Standpoint Theory Reader: Intellectual \& Political Controversies (New York: Routledge, 2004).

Harding, Sandra. "Standpoint Theories: Productively Controversial" (2009) Hypatia 192. Hartstock, Nancy. "The Feminist Standpoint: Developing A Ground for a Specifically Feminist Historical Materialism" in Sandra Harding ed, The Feminist Standpoint Theory Reader: Intellectual \& Political Controversies (New York: Routledge, 2004).

Harraway, Donna. "Situated Knowledges: The Science in Question in Feminism and the Privilege of Partial Perspectives" in Sandra Harding ed, The Feminist Standpoint 
Theory Reader: Intellectual \& Political Controversies (New York: Routledge, 2004) 81 .

Hunt, Kristin. "Classroom Cons and Assigning Activism: Ethical Issues in Relational Pedagogy" (2015) 25 Theatre Topics 199.

Imai, Shin. "A Counter-Pedagogy for Social Justice: Core Skills for Community-Based Lawyering” (2002) 9 Clinical Law Review 195.

Jaggar, Alison M. "Feminist Politics and Epistemology" in Sandra Harding ed, The Feminist Standpoint Theory Reader: Intellectual \& Political Controversies (New York, Routledge: 2004).

Jozkowski, K.N., Peterson, Z.D., Sanders, S.A., Dennis, B., \& Reece, M. “Gender Differences in Heterosexual College Students' Conceptualizations and Indicators of Consent: Implications for Contemporary Sexual Assault Prevention Education” (2014) 51 The Journal of Sex Research 904.

Kauffman, Laura. "The Long Goodbye: Against Personal Testimony or An Infant Grifter Grows Up" in Linda Kaufman ed, American Feminist Thought at Century's End: A Reader (Oxford: Blackwell, 1993).

Koggel, Christine M. "A Relational Approach to Equality" in Jocelyn Downie and Jennifer L. Llewelyn eds, Being Relational: Reflections on Relational Theory and Health Law (Canada: UBC Press, 2012). 
LaMantia, Kristen., Wagner, Holly., \& Bohecker, Lynn., “Ally Development Through Feminist Pedagogy: A Systemic Focus on Intersectionality” (2015) Journal of LGBT Issues in Counselling 136.

Lewkowich, David. "Reminders of the Abject in Teaching: Psychoanalytical Notes on my Sweaty, Pedagogical Self” 16 Emotion, Space, and Society 41.

Llewellyn, Kristina R. \& Llewellyn, Jennifer J. “A Restorative Approach to Learning: Relational Theory as Feminist Pedagogy in Universities" in Tracy Penny Light, Jane Nicholas, \& Renée Bondy eds, Feminist Pedagogy in Higher Education: Critical Theory and Practice (Canada: Wilfrid Laurier University Press, 2015).

Macdonald, Robert A. \& McMorrow, Thomas B. "Decolonizing Law School” (Paper delivered at the Future of Law School Conference, University of Alberta, September 2013).

MacKinnon, Catharine. "Sexuality, Pornography, and Method: Pleasure Under Patriarchy" (1989) Ethics 314.

Maher, Frances A. "Toward A Richer Theory of Feminist Pedagogy: A Comparison of "Liberation" and "Gender" Models for Teaching and Learning" (1987) Journal of Education 91.

Marriner, Sunny. "Questioning Expert Knowledges" in Elizabeth Sheehy ed, Sexual Assault in Canada: Law, Legal Practice, and Women's Activism (Canada: University of Ottawa Press, 2012) 409. 
Narayan, Uma. "Working Together Across Difference: Some Considerations on Emotions and Political Practice" (1988) Hypatia 31.

Pearce, Jane., \& Down, Barry. "Relational Pedagogy for Student Engagement and Success at University" (2011) Australian Council for Research in Education 483. Pedwell, Carolyn., \& Whitehead, Anne. "Affecting Feminism: Questions of Feeling in Feminist Theory" (2012) 13 Feminist Theory 115.

Rayburn, Corey. "To Catch a Sex Thief: The Burden of Performance in Rape and Sexual Assault Trials" Colum. J. Gender \& L. 437.

Rodgers, Sanda. "Educating for Equality: The Meaning of Feminist Administration for Legal Education in Canada" in Elizabeth Sheehy \& Sheila McIntyre eds., Calling for Change: Women, Law, and the Legal Profession (Ottawa, ON: University of Ottawa Press, 2006).

Sheehy, Elizabeth. "The Victories of Jane Doe" in Elizabeth Sheehy eds, Sexual Assault in Canada: Law, Legal Practice, and Women's Activism (Canada: University of Ottawa Press, 2012).

Sheridan, Susan. "Feminist Knowledge: Women's Liberation and Women's Studies" in Sneja Gunew ed, Feminist Knowledge: Critique \& Construct (New York: Routledge, 1990). 
Smith, Dorothy E. "Women's Perspectives as a Radical Critique of Sociology" in Sandra Harding ed, The Feminist Standpoint Theory Reader: Intellectual \& Political Controversies (New York: Routledge, 2004).

Spencer, Dale. "Event and Victimization" (2011) Criminal Law and Philosophy 39.

Thornton, Margaret. “Universities Upside Down: The Impact of New Knowledge Economy” in Meg Luxton \& Mary Jane Mossman eds, Reconsidering Knowledge: Feminism and the Academy (Canada: Fernwood Publishing, 2012).

Weiler, Kathleen. "Rereading Paulo Freire" in Kathleen Weiler eds, Feminist Engagements: Reading, Resisting, and Revisioning Male Theorists in Education and Cultural Studies (New York, NY: Routledge, 2001).

Widdowfield, Rebekah. "The Place of Emotions in Academic Research" (2000) Area 199.

\section{SECONDARY MATERIALS: BOOKS}

Ahmed, Sarah. Living a Feminist Life (Durham, NC: Duke University Press, 2017).

Bannerji, Himani., ed, Returning the Gaze: Essays on Race, Feminism, and Politics (Toronto, ON: Sister Vision Press, 1993).

Bingham, Charles., \& Sidorkin, Alexander M., ed, No Education Without Relation (New York: Peter Lang, 2004).

Bourriard, Nicholas. Relational Aesthetics (France: Les Presse Du Reel, 1998).

Bovy, Phoebe Maltz. The Perils of Privilege: Why Injustice Can't Be Solved by Accusing Others of Advantage (New York: St. Martin's Press, 2017). 
Briskin, Linda. Feminist Pedagogy: Teaching and Learning Liberation (Ottawa: CRIAW, 1992).

Butler, Judith. Bodies That Matter: On the Discursive Limits of Sex (New York: Routledge, 1993).

Butler, Judith. Undoing Gender (New York: Routledge, 2004).

Butler, Judith. Gender Trouble (New York: Routledge Classics, 2006)

Code, Lorraine. What Can She Know? Feminist Theory and the Construction of Knowledge (New York: Cornell University Press, 1991).

Cote-Meek, Sheila. Colonized Classrooms: Racism, Trauma and Resistance in PostSecondary Education (Canada: Fernwood Publishing, 2014).

Crabtree, Robbin D., Sapp, David Alan., \& Licona Adela C., eds, Feminist Pedagogy: Looking Back to Move Forward (Baltimore, MD: The Johns Hopkins University Press, 2004).

Crenshaw, Kimberlé., Gotanda, Neil., Peller, Gary., \& Thomas, Kendall., eds, Critical Race Theory: The Key Writings that Formed the Movement (New York: The New Press, 1995).

de Beauvoir, Simone. The Second Sex (New York, NY: Vintage Books, 1989).

DeKeseredy, Walter S. Violence Against Women: Myths, Facts, Controversies (Canada: University of Toronto Press, 2011).

de Lauretis, Teresa. Alice Doesn't Know: Feminism, Semiotics, Cinema (United Kingdom: The Macmillan Press, 1984). 
Doe, Jane. The Story of Jane Doe: A Book About Rape (Canada: Vintage Canada, 2004).

Downie, Jocelyn., \& Jennifer L. Llewellyn, Jennifer J., eds, Being Relational: Reflections on Relational Theory and Health Law (Canada: UBC Press, 2012).

Fanon, Frantz. The Wretched of The Earth, translated by Richard Philcox, (New York: Grove Press, 2004).

Foucault, Michel. Discipline and Punish: The Birth of a Prison (New York, NY: Vintage, 1977).

Foucault, Michel. The History of Sexuality Volume I: An Introduction (New York: Random House, 1978).

Foucault, Michel. The Archaeology of Knowledge and the Discourse on Language (New York: Vintage, 2006).

Freire, Paulo. Pedagogy of Freedom: Ethics, Democracy, and Civic Courage (Maryland: Rowan \& Littlefield Publishers, 1998).

Freire, Paulo. Pedagogy of the Oppressed: $30^{\text {th }}$ Anniversary Edition (New York: Bloomsbury, 2000).

Gunew, Sneja. ed, Feminist Knowledge: Critique and Construct (New York: Routledge, 1990).

Gunew, Sneja. ed, A Reader in Feminist Knowledge (New York: Routledge, 1991).

Harding, Sandra. ed, The Feminist Standpoint Theory Reader: Intellectual \& Political Controversies (New York: Routledge, 2004). 
Hartstock, Nancy. The Feminist Standpoint Revisited and Other Essays (Boulder: Westview Press, 1998).

Henry, Frances., Dua, Enakshi., James, Carl E., Kobayashi, Aubrey., Li, Peter., Ramos, Howard., \& Smith, Malinda S., The Equity Myth: Racialization and Indigeneity at Canadian Universities (Canada: UBC Press, 2017).

hooks, bell. Feminist Theory: From Margin to Center (Cambridge, MA: South End Press, 1984).

hooks, bell. Ain't I A Woman: Black Women and Feminism (Boston, MA: South End Press, 1991).

hooks, bell. Sisters of the Yam: Black Women \& Self-Recovery (Toronto, ON: Between The Lines, 1993).

hooks, bell. Teaching to Transgress: Education as the Practice of Freedom (New York: Routledge, 1994).

hooks, bell. Teaching Community: A Pedagogy of Hope (New York: Routledge, 2003). hooks, bell. The Will to Change: Men, Masculinity, and Love (New York: Washington Square Press, 2004).

hooks, bell. Feminism is For Everybody: Passionate Politics (Brooklyn, NY: South End Press, 2006).

Laing, Lesley. "Secondary Victimization: Domestic Violence Survivors Navigating the Family Law System” (2017) 23 Violence Against Women 1314. 
Lather, Patti. Getting Smart: Feminist Research and Pedagogy With/In the Postmodern (New York: Routledge, 1991).

Light, Penny., Nicholas, Jane., \& Bondy, Renée., eds, Feminist Pedagogy in Higher Education: Critical Theory and Practice (Waterloo, ON: Wilfred Laurier University Press).

Luxton, Meg., \& Mossman, Mary Jane., eds, Reconsidering Knowledge: Feminism and the Academy (Canada: Fernwood Publishing, 2012).

Manfredi, Christopher P., Feminist Activism in the Supreme Court: Legal Mobilization and the Women's Legal Education and Action Fund (Canada: UBC Press, 2004).

Mann, Susan Archer. Doing Feminist Theory: From Modernity to Postmodernity (New York: Oxford University Press, 2012).

Maynes, Mary Jo., Pierce, Jennifer L., \& Laslett, Barbara., eds, Telling Stories: The Use of Personal Narratives in the Social Sciences and History (New York, NY: Cornell University Press, 2008).

Moran, Robin. ed, Sisterhood is Forever: The Women's Anthology for a New Millennium (New York: Washington Square Press, 2003).

Ngai, Sianne. Ugly Feelings (Cambridge, MA: Harvard University Press, 2007).

O’Toole, Laura L. \& Schiffman, Jessica R., eds, Gender Violence: Interdisciplinary Perspectives (New York: New York University Press, 1997).

Patterson, Debra. “The Linkage Between Secondary Victimization by Law Enforcement and Rape Case Outcomes" (2011) 26 Journal of Interpersonal Violence. 
Richardson, Diane., McLaughlin, Janice., \& Casey, Mark E., eds, Intersections Between Feminist and Queer Theory (United Kingdom: Palgrave Macmillan, 2006).

Schulman, Sarah. Conflict is Not Abuse: Overstating Harm, Community Responsibility, and the Duty of Repair (Vancouver, BC: Arsenal Pulp Press, 2016).

Sheehy, Elizabeth. \& McIntrye, Sheila. eds, Calling For Change: Women, Law, and the Legal Profession (Canada: University of Ottawa Press, 2006).

Sheehy, Elizabeth. ed, Sexual Assault in Canada: Women, Law, and Legal Activism (Canada: University of Ottawa Press, 2012).

Sheehy, Elizabeth. Defending Battered Women on Trial: Lessons from the Transcripts (Canada: UBC Press, 2014).

Smith, Dorothy E. The Everyday World as Problematic: A Feminist Sociology of Knowledge (Boston, MA: Northeastern University Press, 1987).

Spade, Dean. Normal Life: Administrative Violence, Critical Trans Politics, and the Limits of the Law (Brooklyn, NY: South End Press, 2011).

Spencer, Dale., Walby, Kevin., \& Hunt, Alan., eds, Emotions Matter: A Relational Approach to Emotions (Canada: University of Toronto Press, 2012).

Stauffer, Jill. Ethical Loneliness: The Injustice of Not Being Heard (New York: Columbia University Press, 2015).

SECONDARY SOURCES: ELECTRONIC MATERIAL 
Spade, Dean. "For Those Considering Law School" Blog post. Retrieved from:

$<$ http://www.deanspade.net/wp-content/uploads/2010/10/For-Those-ConsideringLaw-School-Nov 2010.pdf $>$.

\section{OTHER MATERIAL: REPORTS}

Canadian Bar Association, Touchstones for Change: Equality, Diversity, and Accountability - A Report on Gender Equality in the Legal Profession (Ottawa: Canadian Bar Association, 1993).

Changing Attitudes, Changing Lives: Ontario's Sexual Violence Action Plan (Ottawa: Minister Responsible for Women's Issues, March 2011).

It's Never Okay: An Action Plan to Stop Sexual Violence and Harassment (Ottawa:

Minister Responsible for Women's Issues, March 2015)

Bill C-46: Records Applications, Post-Mills, A Caselaw Review (Department of Justice Canada, 2004).

Bill C-337: Judicial Accountability Through Sexual Assault Law Training Act (Ottawa: The Canadian Bar Association, 2017).

\section{OTHER MATERIAL: COURSE MATERIALS}

Calder, Gillian. Violence in Relationships, Lecture Outline (Faculty of Law, University of Victoria, Fall 2016).

Calder, Gillian. Intimate Violence, Lecture outline, (Faculty of Law, University of Victoria, Fall 2016). 
Calder, Gillian. Sexual Orientation and The Law, Course Syllabus (Faculty of Law, University of Victoria, Fall 2017).

Calder, Gillian. Sexual Orientation and The Law, Reading Outline (Faculty of Law, University of Victoria, Fall 2017).

Tamas, Sophie. Emotional Geographies, Course Syllabus (Faculty of Canadian Studies, Carleton University, Winter 2017).

\section{OTHER MATERIAL: PLAYS}

Boal, Augusto. Theatre of the Oppressed (New York: Theatre Communications Group, 1985).

Boal, Augusto. Games for Actors and Non-Actors, Second Edition (London: Routledge, 2002).

de Guevara, Lina. "Canadian Tango" (Victoria: Puente Theatre, 1991). 